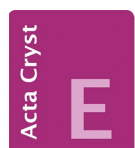

CRYSTALLOGRAPHIC COMMUNICATIONS

ISSN 2056-9890

Received 7 April 2017

Accepted 13 April 2017

Edited by M. Weil, Vienna University of Technology, Austria

₹ Additional correspondence author, e-mail: j.wardell@abdn.ac.uk.

Keywords: crystal structure; co-crystal; naphthalene-1,4-dione; dihydroxyanthracene-9,10dione; Hirshfeld surface analysis.

CCDC reference: 1543933

Supporting information: this article has supporting information at journals.iucr.org/e

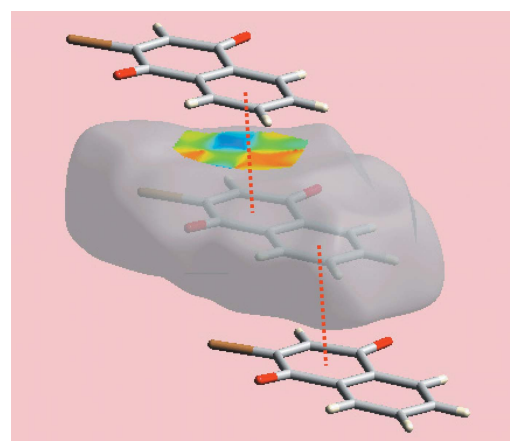

OPEN $\odot$ ACCESS

\section{The 1:1 co-crystal of 2-bromonaphthalene-1,4- dione and 1,8-dihydroxyanthracene-9,10-dione: crystal structure and Hirshfeld surface analysis}

\author{
Marlon D. L. Tonin, ${ }^{\text {a }}$ Simon J. Garden, ${ }^{\text {a }}$ Mukesh M. Jotani, ${ }^{\text {b }}$ Solange M. S. V. \\ Wardell, ${ }^{\mathrm{c}}$ James L. Wardell ${ }^{\mathrm{d}, \mathrm{e}} \neq$ and Edward R. T. Tiekink ${ }^{\mathrm{f}}$.
}

\begin{abstract}
anstituto de Química, Universidade Federal do Rio de Janeiro, Centro Tecnológica, Bloco A, Cidade Universitária, Ilha do Fundão, 21949-909 Rio de Janeiro, RJ, Brazil, 'b Department of Physics, Bhavan's Sheth R. A. College of Science, Ahmedabad, Gujarat 380 001, India, ${ }^{\mathbf{C}} \mathrm{CHEMSOL}, 1$ Harcourt Road, Aberdeen AB15 5NY, Scotland, ${ }^{\mathbf{d}}$ Fundaçaö Oswaldo Cruz, Instituto de Tecnologia em Fármacos-Far Manguinhos, 21041-250 Rio de Janeiro, RJ, Brazil, ${ }^{\mathbf{e}}$ Department of Chemistry, University of Aberdeen, Old Aberdeen, AB24 3UE, Scotland, and ${ }^{\mathfrak{f}}$ Research Centre for Chemical Crystallography, School of Science and Technology, Sunway University, 47500 Bandar Sunway, Selangor Darul Ehsan, Malaysia. *Correspondence e-mail: edwardt@sunway.edu.my
\end{abstract}

The asymmetric unit of the title co-crystal, $\mathrm{C}_{10} \mathrm{H}_{5} \mathrm{BrO}_{2} \cdot \mathrm{C}_{14} \mathrm{H}_{8} \mathrm{O}_{4}$ [systematic name: 2-bromo-1,4-dihydronaphthalene-1,4-dione-1,8-dihydroxy-9,10-dihydroanthracene-9,10-dione (1/1)], features one molecule of each coformer. The 2-bromonaphthoquinone molecule is almost planar [r.m.s deviation of the 13 non- $\mathrm{H}$ atoms $=0.060 \AA$, with the maximum deviations of $0.093(1)$ and 0.099 (1) $\AA$ being for the $\mathrm{Br}$ atom and a carbonyl-O atom, respectively]. The 1,8-dihydroxyanthraquinone molecule is planar (r.m.s. deviation for the 18 non$\mathrm{H}$ atoms is $0.022 \AA$ ) and features two intramolecular hydroxy-O$\mathrm{H}$... O (carbonyl) hydrogen bonds. Dimeric aggregates of 1,8-dihydroxyanthraquinone molecules assemble through weak intermolecular hydroxy-O$\mathrm{H}$... O(carbonyl) hydrogen bonds. The molecular packing comprises stacks of molecules of 2-bromonaphthoquinone and dimeric assembles of 1,8-dihydroxyanthraquinone with the shortest $\pi-\pi$ contact within a stack of 3.5760 (9) $\AA$ occurring between the different rings of 2-bromonaphthoquinone molecules. The analysis of the Hirshfeld surface reveals the importance of the interactions just indicated but, also the contribution of additional $\mathrm{C}-\mathrm{H} \cdots \mathrm{O}$ contacts as well as $\mathrm{C}=\mathrm{O} \cdots \pi$ interactions to the molecular packing.

\section{Chemical context}

The formation of co-crystals is one of the major activities of crystal engineering endeavours and is motivated by various considerations. The concept of non-covalent derivatization of active pharmaceutical ingredients (API's) by this technology, in the hope of producing new formulations with improved bioavailability, etc. is a prominent motivation for investigation (Duggirala et al., 2016; Bolla \& Nangia, 2016). Over and above this are applications ranging from enhancing non-linear optical materials, crystallization of materials that normally do not crystallize, optical resolution, etc. (Aakeröy, 2015). The above notwithstanding, the title co-crystal, (I), was isolated serendipiously during attempts to react 2-bromonaphthoquinone with 1,8-dihydroxyanthraquinone. Subsequently, it was shown that an equimolar ethyl acetate (or ethanol) solution of 2-bromonaphthoquinone and 1,8-dihydroxyanthraquinone could be co-crystallized to give the same product. Herein, the crystal and molecular structures of (I) are described along with a detailed analysis of the supramolecular association by means of an analysis of the Hirshfeld surfaces. 
<smiles>O=C1C=C(Br)C(=O)c2ccccc21</smiles><smiles>O=C1c2cccc(O)c2C(=O)c2c(O)cccc21</smiles>

\section{Structural commentary}

The molecular structures of the constituents of (I) are shown in Fig. 1, the asymmetric unit comprising one molecule each of 2-bromonaphthoquinone, Fig. 1a, and 1,8-dihydroxyanthraquinone, Fig. $1 b$. The six carbon atoms comprising the cyclohexa-2,5-diene-1,4-dione ring of the naphthoquinone molecule are not strictly planar with the r.m.s. deviation being $0.030 \AA$; the maximum deviations are $0.025(1)$ and -0.031 (2) $\AA$ for the $\mathrm{C} 4 \mathrm{a}$ and $\mathrm{C} 4$ atoms, respectively. The appended $\mathrm{Br} 1, \mathrm{O} 1$ and $\mathrm{O} 4$ atoms lie, respectively, 0.077 (1), 0.078 (1) and -0.117 (1) $\AA$ out of the plane with the Br1 atom lying to one side of the ring and the carbonyl-O atoms to the other. Overall, the r.m.s. deviation for the best plane defined by the 13 non- $\mathrm{H}$ atoms comprising the naphthoquinone molecule is $0.060 \AA$, with the maximum deviations being 0.093 (1) $\AA$ for atom Br1 and -0.099 (1) $\AA$ for the O4 atom, again with these atoms lying to opposite sides of the plane. With respect to the anthraquinone molecule, the r.m.s. deviation for the 18 non-H atoms is $0.022 \AA$ with the maximum deviations being 0.039 (2) $\AA$ for C(13) and 0.026 (1) $\AA$ for the $\mathrm{C} 19$ and $\mathrm{C} 23$ atoms. As seen from Fig. 1b, the hydroxy-H atoms are orientated to be proximate to the centrally located carbonyl-O atom to form intramolecular hydroxy-OH...O(carbonyl) hydrogen-bonds, Table 1.

\section{Supramolecular features}

In addition to the intramolecular hydroxy-O$\mathrm{H}$. . O (carbonyl) hydrogen-bonds in the anthraquinone molecule, both hydroxy-H atoms from weaker intermolecular hydrogen-bonds with a centrosymmetrically related molecule indicating each hydroxy-H atom is bifurcated, Table 1 . The resulting dimeric aggregate, Fig. $2 a$, is connected by a centrosymmetric planar, eight-membered $\{\cdots \mathrm{HO} \cdots \mathrm{O} \cdots \mathrm{H}\}_{2}$ synthon which incorporates two transannular hydroxy-O-
Table 1

Hydrogen-bond geometry $\left(\AA,^{\circ}\right)$.

\begin{tabular}{|c|c|c|c|c|}
\hline$D-\mathrm{H} \cdots A$ & $D-\mathrm{H}$ & $\mathrm{H} \cdots A$ & $D \cdots A$ & $D-\mathrm{H} \cdots A$ \\
\hline $\mathrm{O} 11-\mathrm{H} 11 O \cdots \mathrm{O} 19$ & $0.83(2)$ & $1.81(2)$ & $2.5766(16)$ & $153(2)$ \\
\hline $\mathrm{O} 18-\mathrm{H} 180 \cdots \mathrm{O} 19$ & $0.83(2)$ & $1.89(2)$ & $2.6097(16)$ & $144(2)$ \\
\hline $\mathrm{O} 11-\mathrm{H} 11 O \cdots \mathrm{O} 19^{\mathrm{i}}$ & $0.83(2)$ & $2.40(2)$ & $2.8730(16)$ & $117(2)$ \\
\hline $\mathrm{O} 18-\mathrm{H} 18 O \cdots \mathrm{O} 11^{\mathrm{i}}$ & $0.83(2)$ & $2.35(2)$ & 2.9677 (17) & $131(2)$ \\
\hline $\mathrm{C} 3-\mathrm{H} 3 \cdots \mathrm{O} 20^{\mathrm{ii}}$ & 0.95 & 2.25 & 3.1657 (18) & 161 \\
\hline $\mathrm{C} 13-\mathrm{H} 13 \cdots \mathrm{O} 1^{\mathrm{iii}}$ & 0.95 & 2.46 & $3.348(2)$ & 156 \\
\hline $\mathrm{C} 15-\mathrm{H} 15 \cdots \mathrm{O} 4^{\mathrm{iv}}$ & 0.95 & 2.56 & $3.4358(18)$ & 153 \\
\hline $\mathrm{C} 17-\mathrm{H} 17 \cdots \mathrm{O} 4^{v}$ & 0.95 & 2.43 & $3.228(2)$ & 141 \\
\hline
\end{tabular}

Symmetry codes: (i) $-x+1,-y,-z+1$; (ii) $x, y-1, z$; (iii) $x,-y-\frac{1}{2}, z+\frac{1}{2}$; (iv) $x, y+1, z ;$ (v) $x+1,-y+\frac{1}{2}, z+\frac{1}{2}$.

$\mathrm{H}$... O (carbonyl) hydrogen bonds. The dimeric aggregates stack along the $b$ axis being surrounded by two columns of similar dimeric aggregates and six columns comprising naphthoquinone molecules, Fig. $2 b$. Connections between columns, leading to a three-dimensional architecture, are of the type $s p^{2}-\mathrm{C}-\mathrm{H} \cdots \mathrm{O}$ (carbonyl) and involve all the remaining carbonyl-O atoms with the $\mathrm{O}$ atom of the naphthoquinone- $\mathrm{C} 4=\mathrm{O} 4$ moiety forming two such contacts, Table 1. Within columns comprising molecules of naphthoquinone, $\pi-\pi$ stacking interactions are noted, i.e. between the $(\mathrm{C} 1-\mathrm{C} 4, \mathrm{C} 4 \mathrm{a}, \mathrm{C} 8 \mathrm{a})$ and $(\mathrm{C} 4 \mathrm{a}, \mathrm{C} 5-\mathrm{C} 8, \mathrm{C} 8 \mathrm{a})$ rings with the intercentroid separation being $3.5760(9) \AA$ and the angle of inclination being $1.64(7)^{\circ}$ for symmetry operation $x,-1+y, z$. The closest comparable interaction within the stack of anthraquinone molecules is 4.1013 (9) $\AA$, i.e. between (C15$\mathrm{C} 21)$ and $(\mathrm{C} 19-\mathrm{C} 24)$ rings; angle of inclination $=0.65(7)^{\circ}$ for symmetry operation: $x,-1+y, z$.
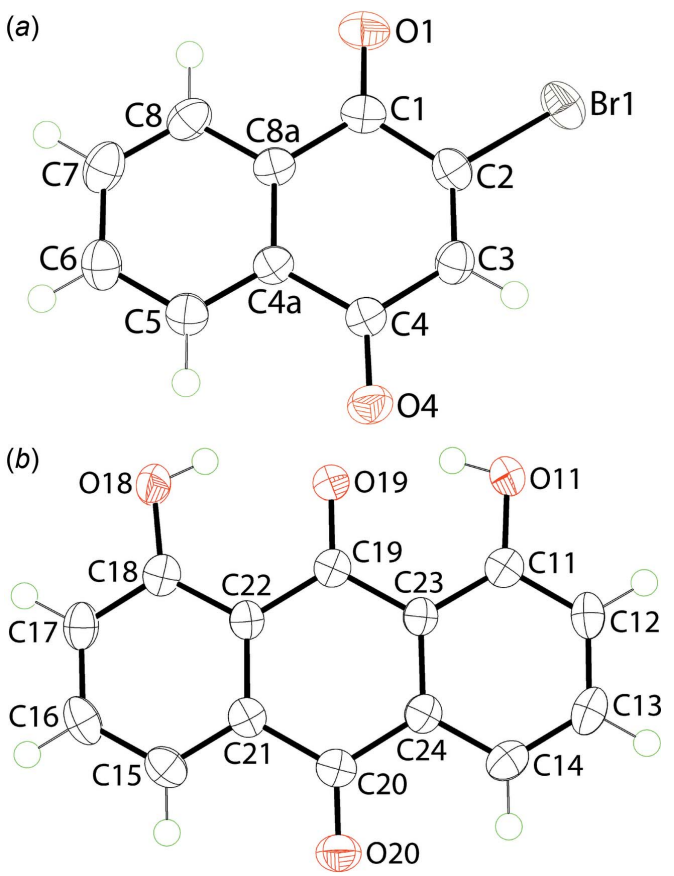

Figure 1

The molecular structures of (a) 2-bromonaphthoquinone and (b) 1,8dihydroxyanthraquinone, i.e. the coformers comprising the asymmetric unit of (I), showing the atom-labelling scheme and displacement ellipsoids at the $70 \%$ probability level. 
(a)

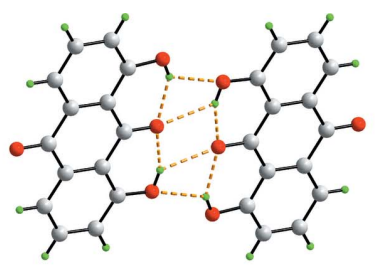

(b)

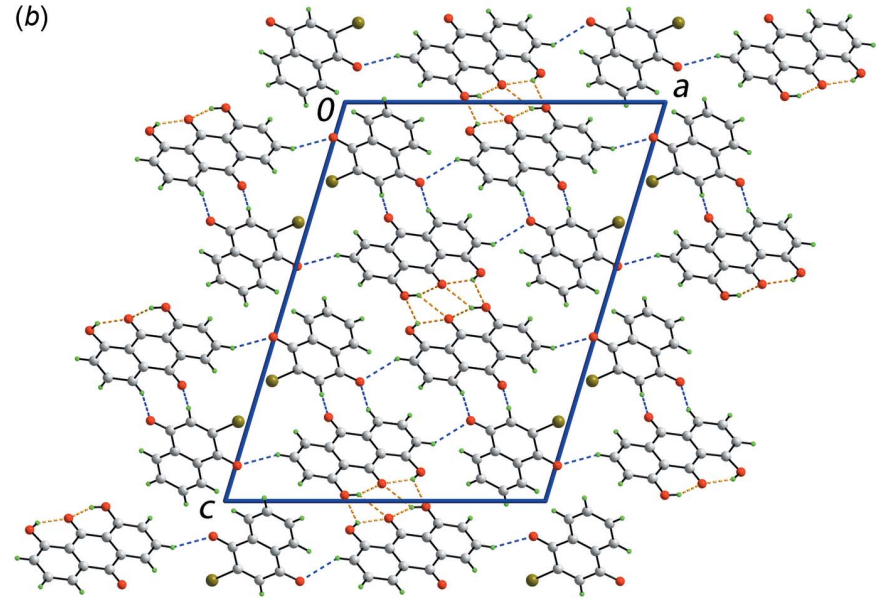

Figure 2

The molecular packing in (I): (a) dimeric aggregate comprising centrosymmetrically related 1,8-dihydroxyanthraquinone molecules connected by hydroxy- $\mathrm{O}-\mathrm{H} \cdots \mathrm{O}$ (carbonyl) hydrogen bonds and $(b)$ a view of the unit-cell contents in projection down the $b$ axis. The $\mathrm{O}-$ $\mathrm{H} \cdots \mathrm{O}$ and phenyl-C $-\mathrm{H} \cdots \mathrm{O}$ (carbonyl) interactions are shown as orange and blue dashed lines, respectively.

\section{Hirshfeld surface analysis}

The Hirshfeld surface analysis of title 1:1 co-crystal, (I), was performed as per recent publications on co-crystals (Syed, Jotani, Halim et al., 2016; Syed, Halim, Jotani et al., 2016) and provides more detailed information on the supramolecular association formed by the individual coformers and overall packing in the crystal. The Hishfeld surfaces are mapped over $d_{\text {norm }}$, Figs. 3 and 4 , the calculated electrostatic potential, Figs. 5 and 6 , and shape-index, Figs. 7 and 8 .

The donors and acceptors of intermolecular hydroxy-O$\mathrm{H}$...O(carbonyl) hydrogen-bonds between anthraquinone molecules are viewed as bright-red spots labelled with ' 1 ' and ' 2 ' on the Hirshfeld surfaces mapped over $d_{\text {norm }}$ in Fig. $3 a$. On the Hirshfeld surface mapped over the calculated electrostatic potential, the respective donors and acceptors appear as the blue (positive potential) and red regions (negative potential) in Fig. $5 a$. The presence of faint-red spots near carbon atoms C11, C19, Fig. $3 a$, and near the atoms C15 and C20, Fig. 3b, also indicate the links between molecules through short interatomic C . . C contacts, Table 2 . These short contacts are also illustrated by white dashed lines in Fig. $6 a$. Links between the coformers involving their carbonyl- $\mathrm{C} 4=\mathrm{O} 4$ and $\mathrm{C} 20=\mathrm{O} 20$ groups through short interatomic $\mathrm{C} \cdot \mathrm{OO} / \mathrm{O} \cdots \mathrm{C}$ contacts, Table 2, are viewed as a pair of bright- and faint-red spots near these atoms in Fig. $3 b$ and $4 b$. This is also illustrated by the black dashed lines on the Hirshfeld surface mapped over
Table 2

Summary of short inter-atomic contacts ( $)$ in (I).

\begin{tabular}{lll}
\hline Contact & distance & symmetry operation \\
\hline $\mathrm{C} 11 \cdots \mathrm{C} 20$ & $3.299(2)$ & $x,-1+y, z$ \\
$\mathrm{C} 15 \cdots \mathrm{C} 19$ & $3.347(2)$ & $x, 1+y, z$ \\
$\mathrm{C} 4 \cdots \mathrm{O} 20$ & $3.0273(18)$ & $x, y, z$ \\
$\mathrm{C} 20 \cdots \mathrm{O} 4$ & $3.1585(18)$ & $x, y, z$ \\
$\mathrm{O} 18 \cdots \mathrm{H} 5$ & 2.60 & $1-x,-\frac{1}{2}+y, \frac{1}{2}-z$ \\
$\mathrm{C} 16 \cdots \mathrm{H} 16$ & 2.89 & $1-x,-\frac{1}{2}+y, \frac{1}{2}-z$ \\
$\mathrm{H} 8 \cdots \mathrm{H} 8$ & 2.27 & $-x, 2-y,-z$ \\
\hline
\end{tabular}

electrostatic potential in Fig. $6 b$. The donors and acceptors of intermolecular $\mathrm{C}-\mathrm{H} \cdots \mathrm{O}$ (carbonyl) interactions can be viewed as bright-red spots having labels ' 3 '-' 5 ' in Figs. 3 and 4, and as blue and red regions, respectively, in Fig. 5. The comparatively weak anthraquinone-C15-H..OO hydrogen bond is represented with faint-red spots near these atoms in Fig. $3 b$ and $4 a$, labelled with ' 6 '. The immediate environments about reference anthraquinone and naphthoquinone mol-

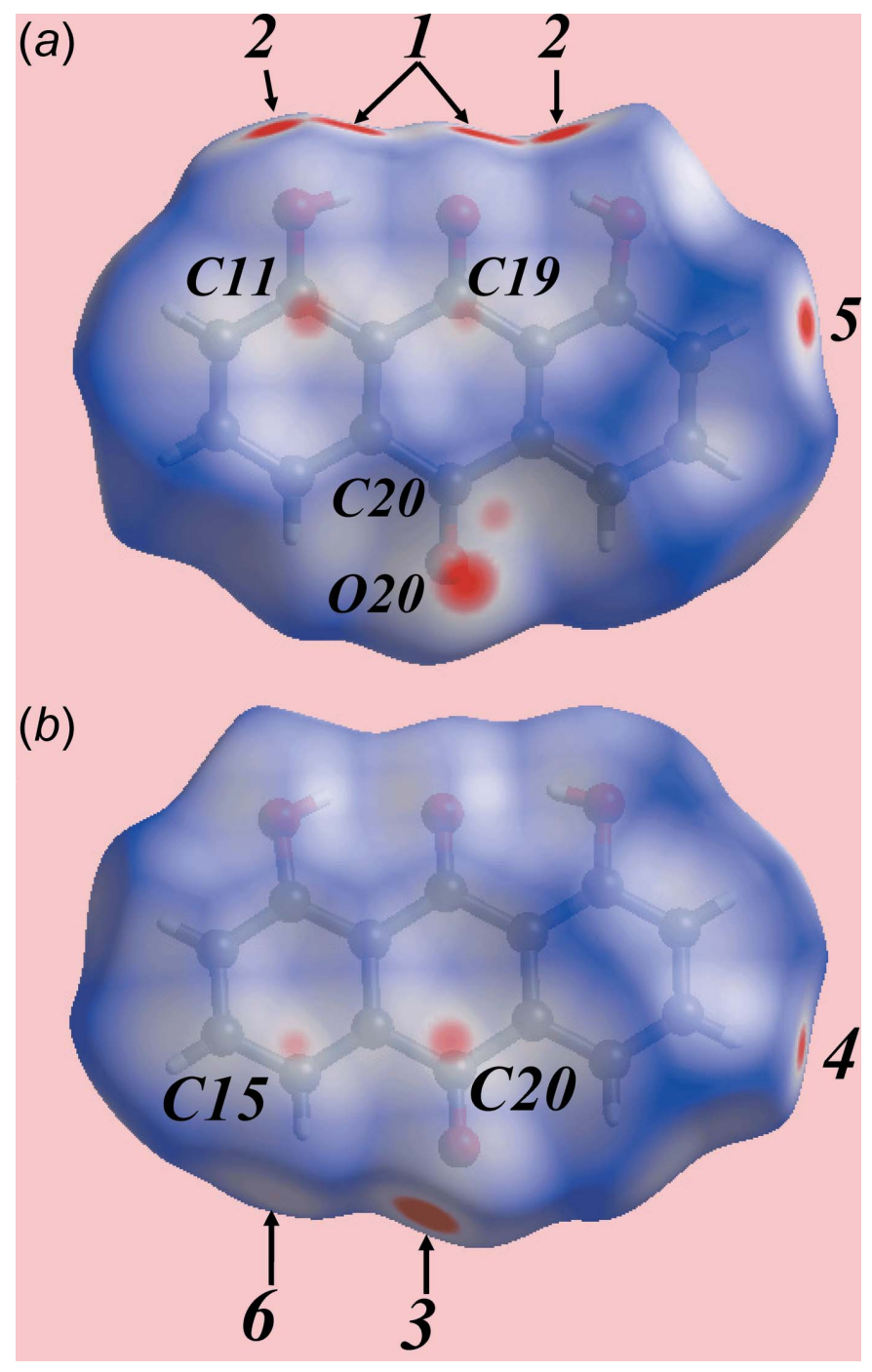

Figure 3

Two views of the Hirshfeld surface for the anthraquinone molecule in (I) mapped over $d_{\text {norm }}$ over the range -0.120 to 1.190 au. 

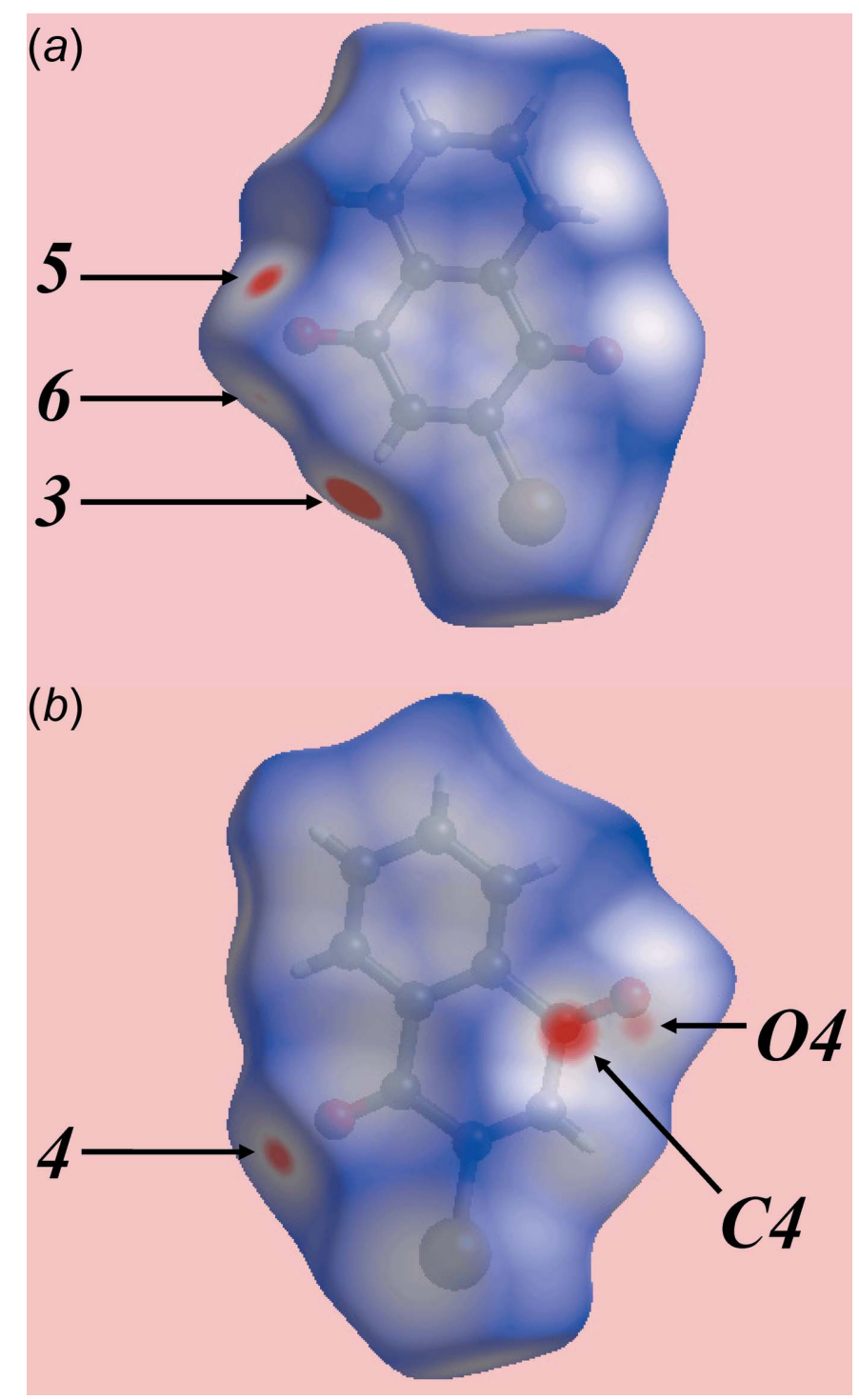

Figure 4

Two views of the Hirshfeld surface for the naphthoquinone molecule in (I) mapped over $d_{\text {norm }}$ over the range -0.125 to 1.157 au.

ecules within shape-index-mapped Hirshfeld surfaces highlighting intermolecular $\mathrm{O}-\mathrm{H} \cdots \mathrm{O}, \mathrm{C}-\mathrm{H} \cdots \mathrm{O}, \pi-\pi$ stacking and $\mathrm{C}-\mathrm{O} \cdots \pi$ interactions influential on the packing are illustrated in Figs. 7 and 8.

The two-dimensional fingerprint plots for the individual naphthoquinone and anthraquinone molecules, and for the overall co-crystal are illustrated in Fig. 9a. The plots delineated into $\mathrm{H} \cdots \mathrm{H}, \mathrm{O} \cdots \mathrm{H} / \mathrm{H} \cdots \mathrm{O}, \mathrm{C} \cdots \mathrm{H} / \mathrm{H} \cdots \mathrm{C}, \mathrm{C} \cdots \mathrm{C}$ and C...O/O ... contacts (McKinnon et al., 2007) are shown in Fig. $9 b-f$, respectively; the relative contributions from various contacts to the Hirshfeld surfaces are quantitatively summarized in Table 3. The different immediate environments of intermolecular interactions around the naphthoquinone and anthraquinone coformers result in different shapes and a distinct distribution of points in the respective delineated fingerprint plots: there is a clear distinction between these and those for the overall co-crystal.
Table 3

Percentage contribution of inter-atomic contacts to the Hirshfeld surface for (I).

\begin{tabular}{llll}
\hline Contact & percentage contribution & & \\
\hline & naphthoquinone & anthraquinone & $(\mathrm{I})$ \\
$\mathrm{H} \cdots \mathrm{H}$ & 20.5 & 21.4 & 20.6 \\
$\mathrm{O} \cdots \mathrm{H} / \mathrm{H} \cdots \mathrm{O}$ & 29.2 & 28.4 & 31.3 \\
$\mathrm{C} \cdots \mathrm{H} / \mathrm{H} \cdots \mathrm{C}$ & 15.2 & 25.2 & 20.2 \\
$\mathrm{C} \cdots \mathrm{C}$ & 9.7 & 7.1 & 9.3 \\
$\mathrm{C} \cdots \mathrm{O} / \mathrm{O} \cdots \mathrm{C}$ & 3.9 & 11.9 & 5.4 \\
$\mathrm{Br} \cdot \mathrm{H} / \mathrm{H} \cdots \mathrm{Br}$ & 10.0 & 4.1 & 6.5 \\
$\mathrm{Br} \cdots \mathrm{Br}$ & 4.6 & 0.0 & 2.4 \\
$\mathrm{Br} \cdots \mathrm{C} / \mathrm{C} \cdots \mathrm{Br}$ & 5.2 & 0.0 & 2.8 \\
$\mathrm{Br} \cdot \mathrm{O} / \mathrm{O} \cdots \mathrm{Br}$ & 1.1 & 0.1 & 0.7 \\
$\mathrm{O} \cdots \mathrm{O}$ & 0.5 & 1.8 & 0.8 \\
\hline
\end{tabular}

The fingerprint plots delineated into $\mathrm{H} \cdots \mathrm{H}$ contacts arise from relatively low percentage contributions to their respective Hirshfeld surfaces, Table 3, as a result of their relatively their low contents in the molecules and the involvement of

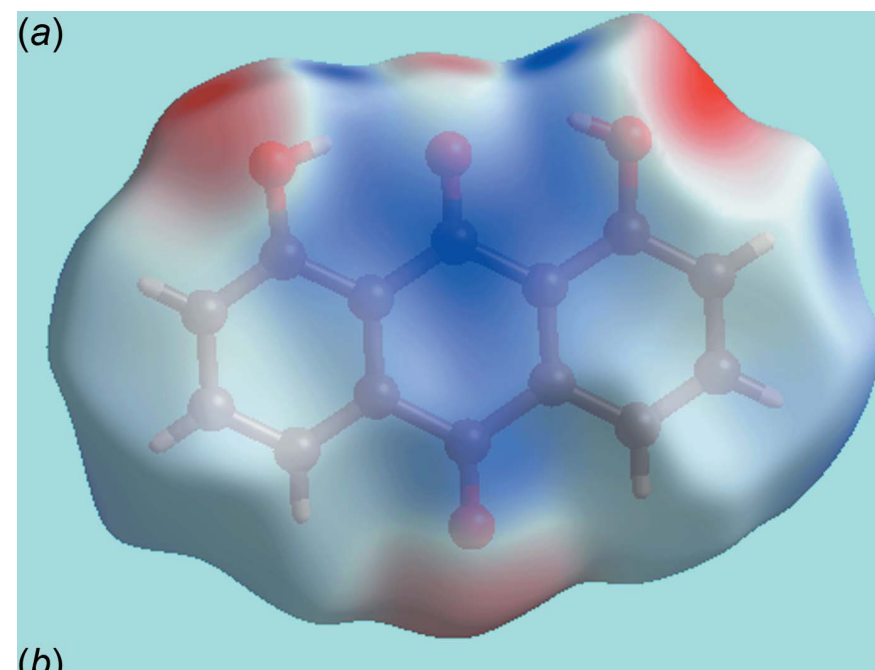

(b)

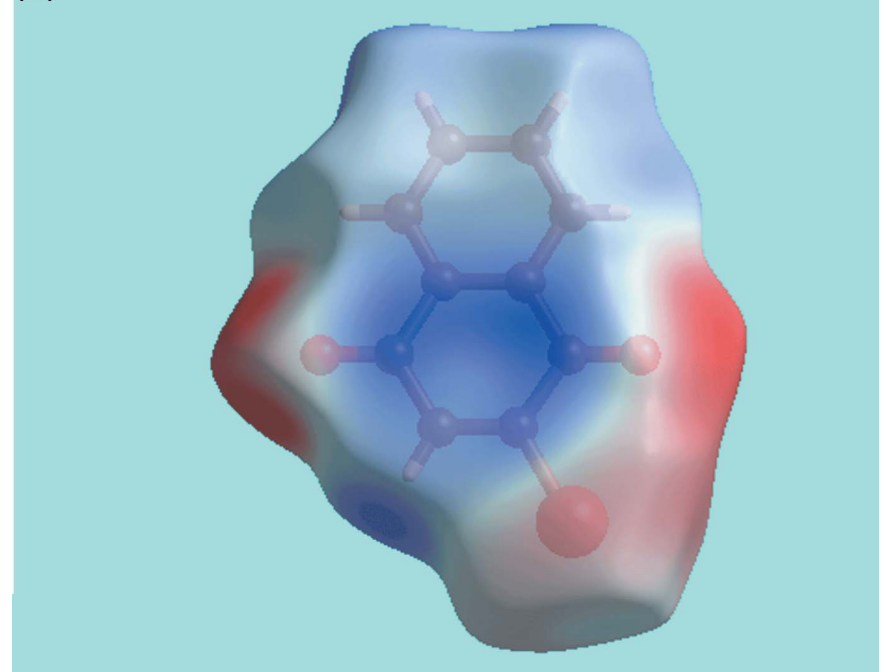

Figure 5

Views of the Hirshfeld surfaces for the $(a)$ anthraquinone and $(b)$ naphthoquinone molecules in (I) mapped over the electrostatic potential in the range $\pm 0.059 \mathrm{au}$. The red and blue regions represent negative and positive electrostatic potentials, respectively. 


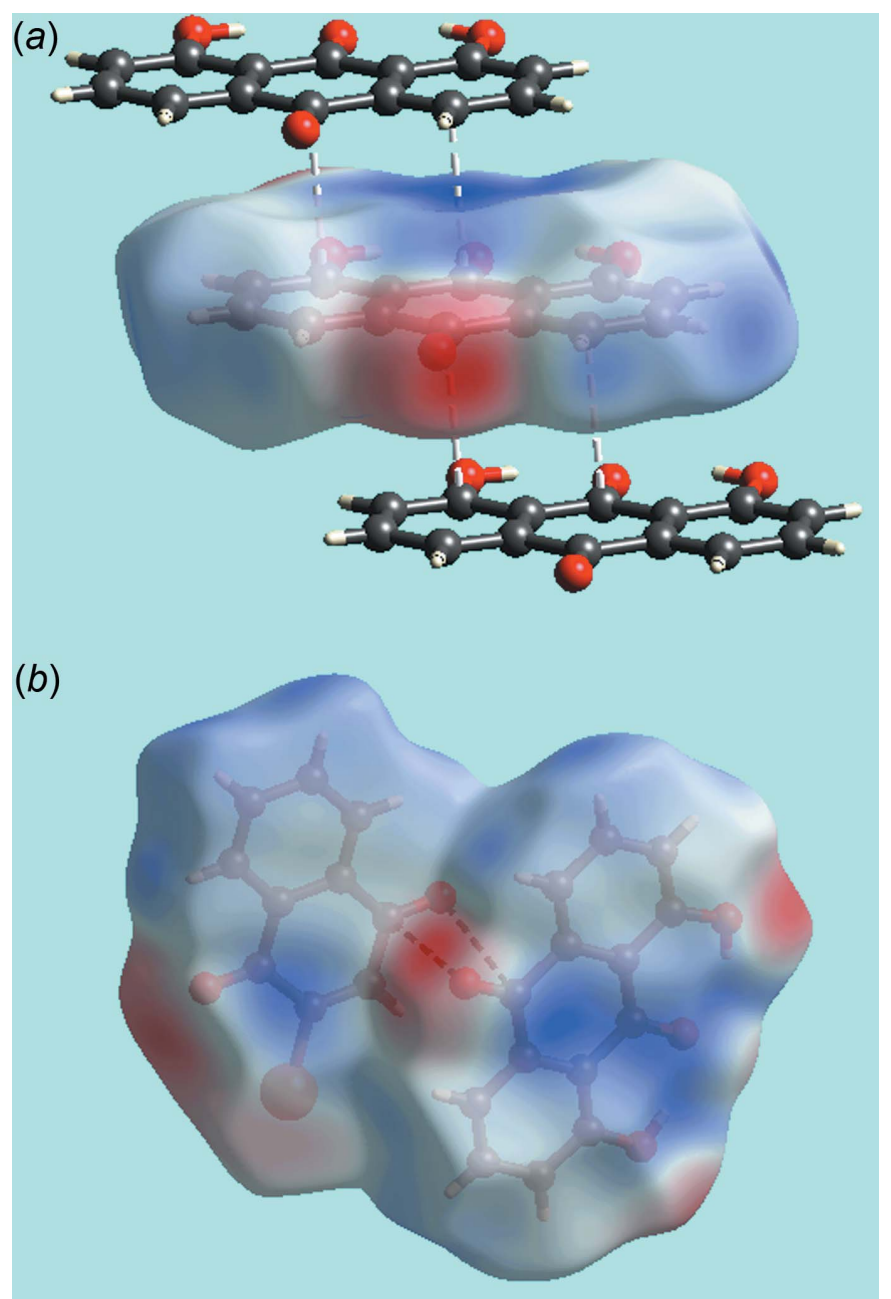

Figure 6

Views of Hirshfeld surfaces for the molecules in (I) mapped over the electrostatic potential highlighting $(a)$ short interatomic $\mathrm{C} \cdots \mathrm{C}$ contacts as with white dashed lines in the stacking of anthraquinone molecules in the range \pm 0.059 au and $(b)$ short interatomic $\mathrm{C} \cdots \mathrm{O} / \mathrm{O} \cdots \mathrm{C}$ contacts as black dashed lines between approximately co-planar anthraquinone and naphthoquinone molecules in the range \pm 0.060 au.

many hydrogen atoms in specific intermolecular interactions. The presence of short interatomic $\mathrm{H} \cdot \mathrm{H}$ contacts between naphthoquinone-H8 atoms, Table 2, is evident in the respective plot as a single peak at $d_{\mathrm{e}}+d_{\mathrm{i}} \sim 2.2 \AA$.

The donors and acceptors of the naphthoquinone- $\mathrm{H} 3$ and anthraquinone-O20(carbonyl) atoms are viewed as a thin, long spike at $d_{\mathrm{e}}+d_{\mathrm{i}} \sim 2.2 \AA$ in each of the fingerprint plots of $\mathrm{O} \cdots \mathrm{H} / \mathrm{H} \cdots \mathrm{O}$ contacts, Fig. $9 c$; the spikes for the donor and acceptor interactions are viewed separately in the plots for the naphthoquinone and anthraquinone coformers, respectively. The $\mathrm{O}-\mathrm{H} \cdots \mathrm{O}$ interactions instrumental in linking anthraquinone molecules are evident in the respective $\mathrm{O} \cdots \mathrm{H} / \mathrm{H} \cdots \mathrm{O}$ delineated plot, Fig. $9 c$, and is characterized by a pair of short spikes at $d_{\mathrm{e}}+d_{\mathrm{i}} \sim 2.3 \AA$ where in the acceptor spike is merged within the plot of the aforementioned $\mathrm{C} 3-\mathrm{H} \cdots \mathrm{O}^{\mathrm{ii}}$ interaction. The other intermolecular $\mathrm{C}-\mathrm{H} \cdots \mathrm{O}$ contacts involving anthraquinone-H13 and - H17, and naphthoquinone-O1 and -O4(carbonyl) atoms are viewed as a pair of short spikes at

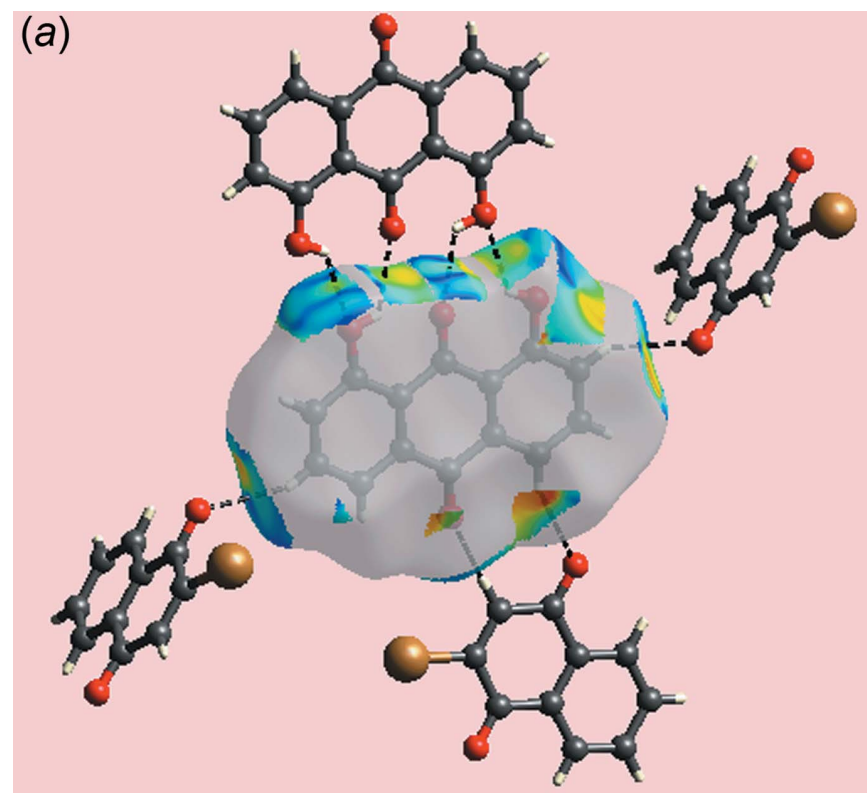

(b)

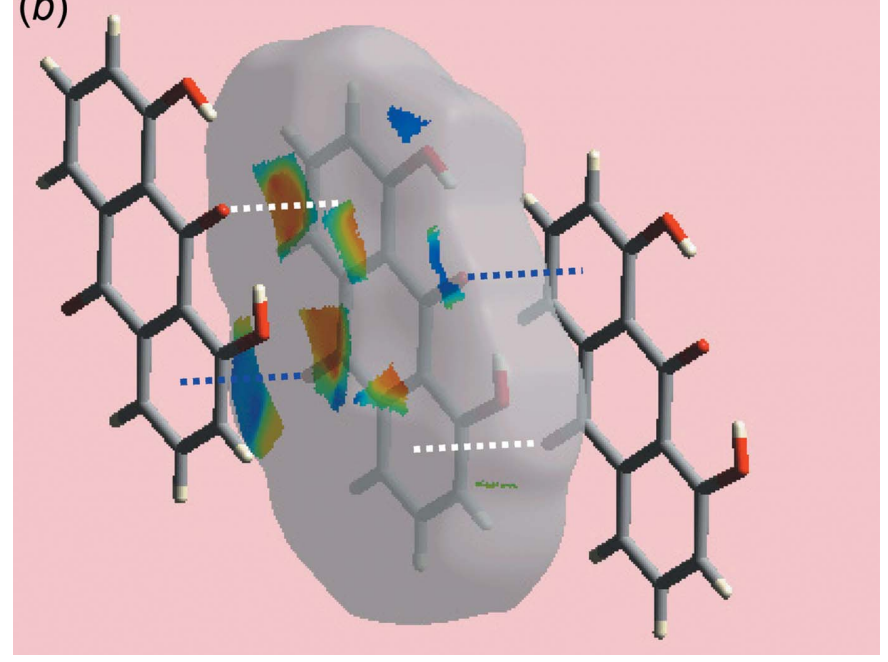

Figure 7

Views of Hirshfeld surface for a reference anthraquinone molecule in (I) mapped over the shape-index property highlighting: (a) $\mathrm{O}-\mathrm{H} \cdots \mathrm{O}$ and $\mathrm{C}-\mathrm{H} \cdots \mathrm{O}$ interactions as black dashed lines and $(b) \mathrm{C}-\mathrm{O} \cdots \pi$ and reciprocal $\pi \cdots \mathrm{O}-\mathrm{C}$ interactions as blue and white dotted lines, respectively.

$d_{\mathrm{e}}+d_{\mathrm{i}} \sim 2.4 \AA$ in the donor and acceptor regions of their respective plots in Fig. 9c. The points corresponding to anthraquinone-C15-H15 ..O 4(carbonyl) interactions and other short interatomic $\mathrm{O} \cdots \mathrm{H}$ contacts, Table 2, are merged within the plots.

A pair of short peaks at $d_{\mathrm{e}}+d_{\mathrm{i}}<2.9 \AA$, i.e. less than sum of their van der Waals radii, in the fingerprint plot delineated into $\mathrm{C} \cdots \mathrm{H} / \mathrm{H} \cdots \mathrm{C}$ contacts for anthraquinone, Fig. $9 d$, are indicative of short interatomic $\mathrm{C} \cdot \mathrm{H}$ contacts, Table 2 , in the crystal. The remaining interatomic $\mathrm{C} \cdot \mathrm{H} / \mathrm{H} \cdots \mathrm{C}$ contacts in the crystal are beyond van der Waals separations but still make notable contributions to the Hirshfeld surfaces. The 9.7\% contribution from C.C.C contacts to the Hirshfeld surface of the naphthoquinone coformer is the result of $\pi-\pi$ stacking interaction between its symmetry related 
Table 4

Summary of $\mathrm{C}=\mathrm{O} \cdots \pi$ contacts $\left(\AA,^{\circ}\right)$ in $(\mathrm{I})$.

$C g 1$ and $C g 2$ are the centroids of the $\mathrm{C} 11-\mathrm{C} 14 / \mathrm{C} 24 / \mathrm{C} 23$ and $\mathrm{C} 15-\mathrm{C} 18 / \mathrm{C} 22 / \mathrm{C} 21$ rings, respectively.

\begin{tabular}{lllllll}
\hline$Y$ & $X$ & $C g$ & $X \cdots C g$ & $Y-X \cdots C g$ & $Y \cdots C g$ & $\begin{array}{l}\text { symmetry } \\
\text { operation }\end{array}$ \\
\hline C20 & O20 & $C g 1$ & $3.2667(12)$ & $85.61(8)$ & $3.3999(16)$ & $x, 1+y, z$ \\
C19 & O19 & $C g 2$ & $3.3191(12)$ & $85.51(8)$ & $3.4551(16)$ & $x,-1+y, z$ \\
\hline
\end{tabular}

$(\mathrm{C} 1-\mathrm{C} 4, \mathrm{C} 4 \mathrm{a}, \mathrm{C} 8 \mathrm{a})$ and $(\mathrm{C} 4 \mathrm{a}, \mathrm{C} 5-\mathrm{C} 8, \mathrm{C} 8 \mathrm{a})$ rings and is highlighted as the parabolic distribution of points in Fig. $9 e$, having high density at around $d_{\mathrm{e}}=d_{\mathrm{i}} \sim 1.8 \AA$. The parabolic distribution of points with the peak at $d_{\mathrm{e}}=d_{\mathrm{i}} \sim 1.6 \AA$ in the plot for the anthraquinone coformer, Fig. $9 e$, indicates links between these molecules through short interatomic C.C.C contacts

(a)

(b)
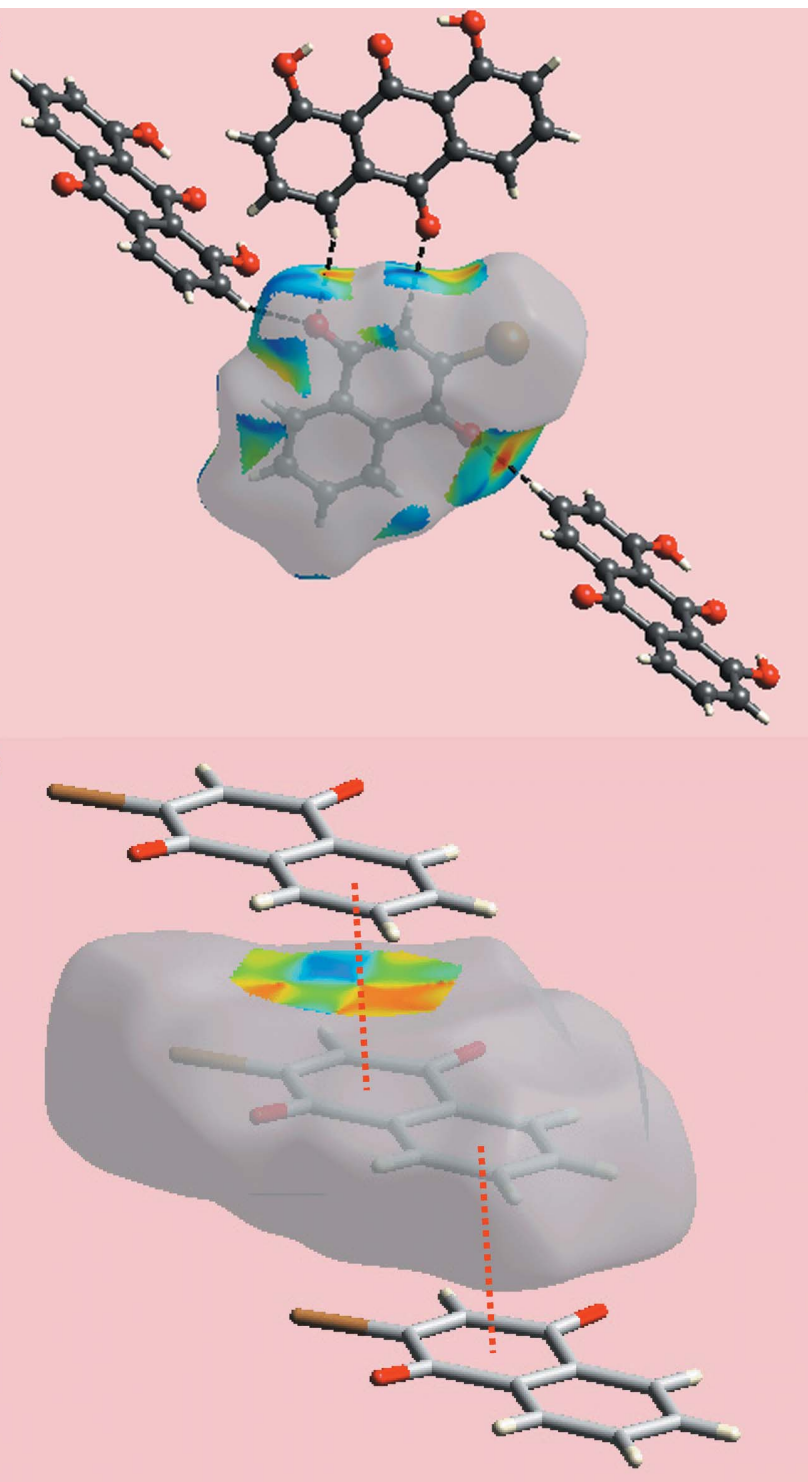

Figure 8

Views of Hirshfeld surface for a reference naphthoquinone molecule in (I) mapped over the shape-index property highlighting: (a) $\mathrm{C}-\mathrm{H} \cdots \mathrm{O}$ interactions as black dashed lines and $(b) \pi-\pi$ stacking interaction as red dotted lines. along the $b$ axis. The presence of C.. $\mathrm{C}$ contacts in (I) results in an overall $9.3 \%$ contribution to the Hirshfeld surface.

The $3.9 \%$ contribution from $\mathrm{C} \cdots \mathrm{O} / \mathrm{O} \cdots \mathrm{C}$ contacts to the Hirshfeld surface for the naphthoquinone molecule, Fig. $9 f$, results from short, inter-atomic $\mathrm{C} \cdots \mathrm{O} / \mathrm{O} \cdots \mathrm{C}$ contacts whereas the $11.9 \%$ contribution from $\mathrm{C} \cdots \mathrm{O} / \mathrm{O} \cdots \mathrm{C}$ contacts for the anthraquinone molecule has a contribution from $\mathrm{C}=\mathrm{O} \cdots \pi$ interactions involving carbony-O19 and $-\mathrm{O} 20$ atoms and (C11-C14,C24,C23) and (C15-C18, C22, C21) rings, Table 4. Most of these features disappear in the overall fingerprint plot delineated into these contacts with only features due to the $\mathrm{C}=\mathrm{O} \cdots \pi$ interactions remaining, Fig. $9 f$.

Although the naphthoquinone-bromide substituent makes a notable contribution to the Hirshfeld surface, Table 3, it does not form inter-atomic contacts with other atoms less than sum of the respective van der Waals radii. Therefore, it exerts no significant influence on the packing. The small contribution from $\mathrm{O} \cdots \mathrm{O}$ contacts also has a negligible effect on the packing.

\section{Database survey}

The coformers comprising (I) are relatively unexplored in the crystallographic literature (Groom et al., 2016). For example, the structure of 2-bromonaphthoquinone has only been reported on one previous occasion, namely in its pure form (Gaultier \& Hauw, 1965). This structure presents the same features as the molecule in (I) with the r.m.s deviation of the 13 fitted atoms being $0.059 \AA, c f$. $0.060 \AA$ in (I). More attention has been directed towards 1,8-dihydroxyanthraquinone. The structure of the pure molecule was originally reported in 1965 (Prakash, 1965) and a recent study focussed upon the several polymorphic forms of this compound (Rohl et al., 2008). In all known forms of 1,8-dihydroxyanthraquinone, an essentially planar molecule is observed along with the two intramolecular hydroxy-O-H..O(carbonyl) hydrogenbonds persisting as in (I). A co-crystal of 1,8-dihydroxyanthraquinone is also known, i.e. a 3:1 co-crystal with acetic acid (Cheuk et al., 2015). This structure is particularly notable in that there are six independent 1,8-dihydroxyanthraquinone molecules in the asymmetric unit, each with the same conformation as in the parent compound and in (I), along with two independent acetic acid molecules.

\section{Synthesis and crystallization}

Compound (I) was isolated during attempts to chemically bond 2-bromonaphthoquinone and 1,8-dihydroxyanthraquinone under basic conditions. Upon work up of the reaction mixture, the crude material was obtained after evaporation of all the volatiles. This was filtered through a short column of silica gel eluting with $\mathrm{CH}_{2} \mathrm{Cl}_{2} /$ hexane $(1: 1 v / v)$ and a single, yellow fraction was collected. After evaporation of the solvent under reduced pressure, a yellow solid was obtained. This was recrystallized from ethyl acetate solution to give small orangered crystals with yields of $78-85 \%$ based upon the quantity of 1,8-dihydroxyanthraquinone initially used. Notably, the 
(a)

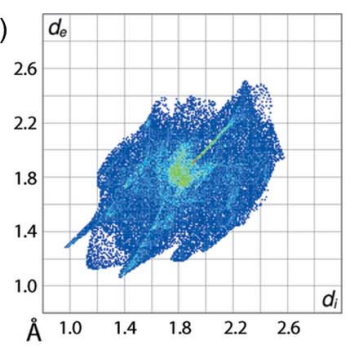

(b)

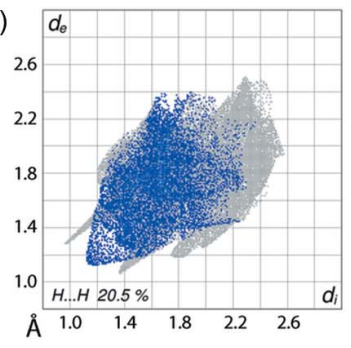

(c)

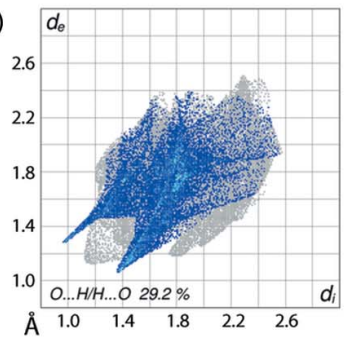

(d)

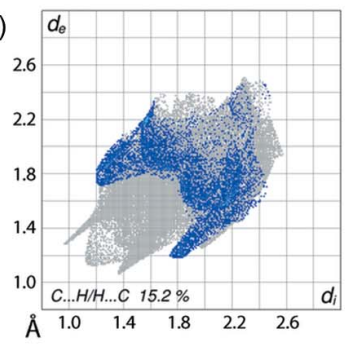

(e)

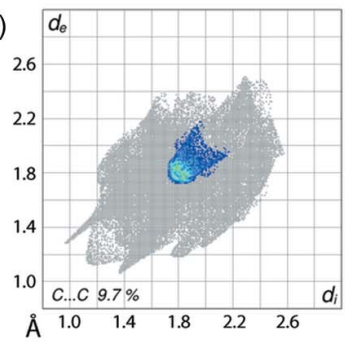

$(f)$

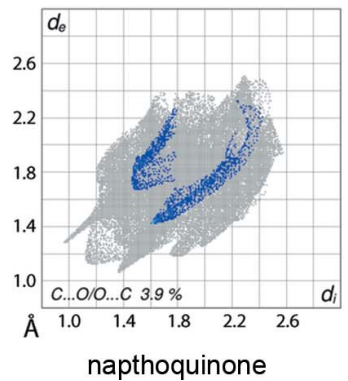

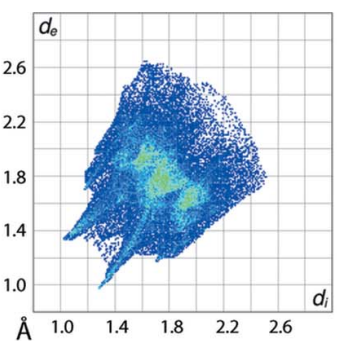
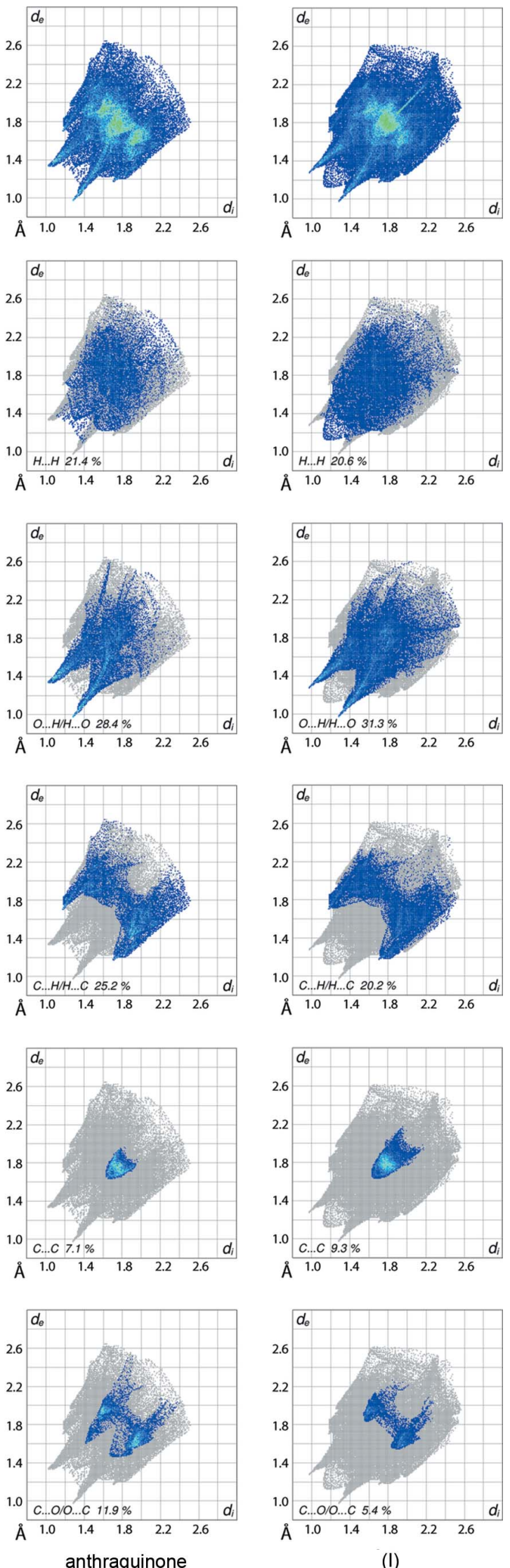

Figure 9

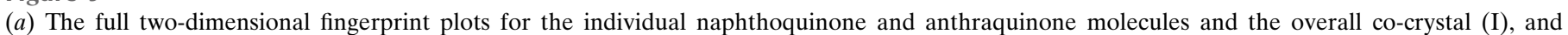
fingerprint plots delineated into $(b) \mathrm{H} \cdots \mathrm{H},(c) \mathrm{O} \cdots \mathrm{H} / \mathrm{H} \cdots \mathrm{O},(d) \mathrm{C} \cdots \mathrm{H} / \mathrm{H} \cdots \mathrm{C},(e) \mathrm{C} \cdots \mathrm{C}$ and $(f) \mathrm{C} \cdots \mathrm{O} / \mathrm{O} \cdots \mathrm{C}$ contacts. 
substrates 2-bromonaphthoquinone and 1,8-dihydroxyanthraquinone could not be chromatographically distinguished as they ran with equivalent $R_{\mathrm{f}}$ 's in a wide range of solvents and solvent mixtures. NMR spectra $\left({ }^{1} \mathrm{H}\right.$ and $\left.{ }^{13} \mathrm{C}\right)$ were consistent with a one to one mixture of the same components as there was no deviation of chemical shifts in comparison to the spectra of the individual components. A sample of the cocrystal material had a well defined melting point of 413-414 K, which is intermediate between the melting points of the pure components 2-bromonaphthoquinone, 405-406 K (Brimble et al., 2007) and 1,8-dihydroxyanthraquinone, 465-466 K (Cameron et al., 1982).

\section{Refinement}

Crystal data, data collection and structure refinement details are summarized in Table 5. Carbon-bound $\mathrm{H}$ atoms were placed in calculated positions $(\mathrm{C}-\mathrm{H}=0.95 \AA)$ and were included in the refinement in the riding-model approximation, with $U_{\text {iso }}(\mathrm{H})$ set to $1.2 U_{\text {eq }}(\mathrm{C})$. The $\mathrm{O}$-bound $\mathrm{H}$ atoms were located from a difference map but refined with $\mathrm{O}-\mathrm{H}=$ $0.84 \pm 0.01 \AA$ and $U_{\text {iso }}(\mathrm{H})=1.5 U_{\text {eq }}(\mathrm{O})$.

\section{Acknowledgements}

The authors thank the National Crystallographic Service, based at the University of Southampton, for collecting the data. The authors also thank the following Brazilian agencies CAPES, CNPq and FAPERJ for financial assistance, and are also grateful to Sunway University (INT-RRO-2017-096) for supporting this research.

\section{Funding information}

Funding for this research was provided by: Sunway University (award No. INT-RRO-2017-096).

\section{References}

Aakeröy, C. (2015). Acta Cryst. B71, 387-391.

Bolla, G. \& Nangia, A. (2016). Chem. Commun. 52, 8342-8360.

Brandenburg, K. (2006). DIAMOND. Crystal Impact GbR, Bonn, Germany.

Brimble, M. A., Bachu, P. \& Sperry, J. (2007). Synthesis, pp. 28872893.

Cameron, D. W., Feutrill, G. I. \& Mckay, P. G. (1982). Aust. J. Chem. 35, 2095-2109.

Cheuk, D., Khamar, D., McArdle, P. \& Rasmuson, Å. C. (2015). J. Chem. Eng. Data, 60, 2110-2118.
Table 5

Experimental details.

\begin{tabular}{|c|c|}
\hline \multicolumn{2}{|l|}{ Crystal data } \\
\hline Chemical formula & $\mathrm{C}_{10} \mathrm{H}_{5} \mathrm{BrO}_{2} \cdot \mathrm{C}_{14} \mathrm{H}_{8} \mathrm{O}_{4}$ \\
\hline$M_{\mathrm{r}}$ & 477.25 \\
\hline Crystal system, space group & Monoclinic, $P 2_{1} / c$ \\
\hline Temperature $(\mathrm{K})$ & 100 \\
\hline$a, b, c(\AA)$ & $\begin{array}{l}17.55090(12), 4.85939(3), \\
22.83423(16)\end{array}$ \\
\hline$\beta\left(^{\circ}\right)$ & $106.7429(7)$ \\
\hline$V\left(\AA^{3}\right)$ & $1864.90(2)$ \\
\hline$Z$ & 4 \\
\hline Radiation type & $\mathrm{Cu} K \alpha$ \\
\hline$\mu\left(\mathrm{mm}^{-1}\right)$ & 3.39 \\
\hline Crystal size $(\mathrm{mm})$ & $0.42 \times 0.05 \times 0.03$ \\
\hline \multicolumn{2}{|l|}{ Data collection } \\
\hline Diffractometer & Rigaku Saturn724+ ( $2 \times 2$ bin mode $)$ \\
\hline Absorption correction & $\begin{array}{l}\text { Multi-scan (CrysAlis PRO; Rigaku } \\
\text { Oxford Diffraction, 2015) }\end{array}$ \\
\hline$T_{\min }, T_{\max }$ & $0.697,1.000$ \\
\hline $\begin{array}{l}\text { No. of measured, independent and } \\
\text { observed }[I>2 \sigma(I)] \text { reflections }\end{array}$ & $27708,3507,3489$ \\
\hline$R_{\text {int }}$ & 0.021 \\
\hline$(\sin \theta / \lambda)_{\max }\left(\AA^{-1}\right)$ & 0.610 \\
\hline \multicolumn{2}{|l|}{ Refinement } \\
\hline$R\left[F^{2}>2 \sigma\left(F^{2}\right)\right], w R\left(F^{2}\right), S$ & $0.025,0.075,1.02$ \\
\hline No. of reflections & 3507 \\
\hline No. of parameters & 286 \\
\hline No. of restraints & 2 \\
\hline $\mathrm{H}$-atom treatment & $\begin{array}{l}\mathrm{H} \text { atoms treated by a mixture of } \\
\text { independent and constrained } \\
\text { refinement }\end{array}$ \\
\hline$\Delta \rho_{\max }, \Delta \rho_{\min }\left(\mathrm{e} \AA^{-3}\right)$ & $0.39,-0.32$ \\
\hline
\end{tabular}

Computer programs: CrysAlis PRO (Rigaku Oxford Diffraction, 2015), SHELXS (Sheldrick, 2008), SHELXL2014 (Sheldrick, 2015), ORTEP-3 for Windows (Farrugia, 2012), DIAMOND (Brandenburg, 2006) and publCIF (Westrip, 2010).

Duggirala, N. K., Perry, M. L., Almarsson, Ö. \& Zaworotko, M. J. (2016). Chem. Commun. 52, 640-655.

Farrugia, L. J. (2012). J. Appl. Cryst. 45, 849-854.

Gaultier, J. \& Hauw, C. (1965). Acta Cryst. 18, 604-608.

Groom, C. R., Bruno, I. J., Lightfoot, M. P. \& Ward, S. C. (2016). Acta Cryst. B72, 171-179.

McKinnon, J. J., Jayatilaka, D. \& Spackman, M. A. (2007). Chem. Commun. pp. 3814-3816.

Prakash, A. (1965). Z. Kristallogr. 122, 272-282.

Rigaku Oxford Diffraction (2015). CrysAlis PRO. Agilent Technologies Inc., Santa Clara, CA, USA.

Rohl, A. L., Moret, M., Kaminsky, W., Claborn, K., McKinnon, J. J. \& Kahr, B. (2008). Cryst. Growth Des. 8, 4517-4525.

Sheldrick, G. M. (2008). Acta Cryst. A64, 112-122.

Sheldrick, G. M. (2015). Acta Cryst. C71, 3-8.

Syed, S., Halim, S. N. A., Jotani, M. M. \& Tiekink, E. R. T. (2016). Acta Cryst. E72, 76-82.

Syed, S., Jotani, M. M., Halim, S. N. A. \& Tiekink, E. R. T. (2016). Acta Cryst. E72, 391-398.

Westrip, S. P. (2010). J. Appl. Cryst. 43, 920-925. 


\section{supporting information}

Acta Cryst. (2017). E73, 738-745 [https://doi.org/10.1107/S2056989017005667]

\section{The 1:1 co-crystal of 2-bromonaphthalene-1,4-dione and 1,8-dihydroxy- anthracene-9,10-dione: crystal structure and Hirshfeld surface analysis}

Marlon D. L. Tonin, Simon J. Garden, Mukesh M. Jotani, Solange M. S. V. Wardell, James L. Wardell and Edward R. T. Tiekink

Computing details

Data collection: CrysAlis PRO (Rigaku Oxford Diffraction, 2015); cell refinement: CrysAlis PRO (Rigaku Oxford Diffraction, 2015); data reduction: CrysAlis PRO (Rigaku Oxford Diffraction, 2015); program(s) used to solve structure: SHELXS (Sheldrick, 2008); program(s) used to refine structure: SHELXL2014 (Sheldrick, 2015); molecular graphics: ORTEP-3 for Windows (Farrugia, 2012) and DIAMOND (Brandenburg, 2006); software used to prepare material for publication: publCIF (Westrip, 2010).

2-Bromo-1,4-dihydronaphthalene-1,4-dione-1,8-dihydroxy-9,10-dihydroanthracene-9,10-dione (1/1)

Crystal data

$\mathrm{C}_{10} \mathrm{H}_{5} \mathrm{BrO}_{2} \cdot \mathrm{C}_{14} \mathrm{H}_{8} \mathrm{O}_{4}$

$M_{r}=477.25$

Monoclinic, $P 2_{1} / c$

$a=17.55090(12) \AA$

$b=4.85939(3) \AA$

$c=22.83423(16) \AA$

$\beta=106.7429(7)^{\circ}$

$V=1864.90(2) \AA^{3}$

$Z=4$

Data collection

Rigaku Saturn724+ (2x2 bin mode) diffractometer

Radiation source: fine-focus sealed X-ray tube, Enhance $(\mathrm{Cu}) \mathrm{X}$-ray Source

Graphite monochromator

$\omega$ scans

Absorption correction: multi-scan

(CrysAlis PRO; Rigaku Oxford Diffraction, 2015)

Refinement

Refinement on $F^{2}$

Least-squares matrix: full

$R\left[F^{2}>2 \sigma\left(F^{2}\right)\right]=0.025$

$w R\left(F^{2}\right)=0.075$

$S=1.02$

3507 reflections
$F(000)=960$

$D_{\mathrm{x}}=1.700 \mathrm{Mg} \mathrm{m}^{-3}$

$\mathrm{Cu} K \alpha$ radiation, $\lambda=1.54184 \AA$

Cell parameters from 22842 reflections

$\theta=2.6-69.9^{\circ}$

$\mu=3.39 \mathrm{~mm}^{-1}$

$T=100 \mathrm{~K}$

Plate, orange

$0.42 \times 0.05 \times 0.03 \mathrm{~mm}$

$T_{\min }=0.697, T_{\max }=1.000$

27708 measured reflections

3507 independent reflections

3489 reflections with $I>2 \sigma(I)$

$R_{\text {int }}=0.021$

$\theta_{\text {max }}=70.2^{\circ}, \theta_{\text {min }}=2.6^{\circ}$

$h=-21 \rightarrow 21$

$k=-5 \rightarrow 4$

$l=-27 \rightarrow 27$

286 parameters

2 restraints

$\mathrm{H}$ atoms treated by a mixture of independent and constrained refinement

$w=1 /\left[\sigma^{2}\left(F_{\mathrm{o}}^{2}\right)+(0.0507 P)^{2}+1.0878 P\right]$

where $P=\left(F_{\mathrm{o}}{ }^{2}+2 F_{\mathrm{c}}{ }^{2}\right) / 3$ 
$(\Delta / \sigma)_{\max }<0.001$

$\Delta \rho_{\max }=0.39$ e $\AA^{-3}$

Special details

Geometry. All esds (except the esd in the dihedral angle between two 1.s. planes) are estimated using the full covariance matrix. The cell esds are taken into account individually in the estimation of esds in distances, angles and torsion angles; correlations between esds in cell parameters are only used when they are defined by crystal symmetry. An approximate (isotropic) treatment of cell esds is used for estimating esds involving l.s. planes.

Fractional atomic coordinates and isotropic or equivalent isotropic displacement parameters $\left(\AA^{2}\right)$

\begin{tabular}{|c|c|c|c|c|}
\hline & $x$ & $y$ & $z$ & $U_{\text {iso }} * / U_{\text {eq }}$ \\
\hline Br1 & $0.03352(2)$ & $0.06602(3)$ & $0.19884(2)$ & $0.02850(9)$ \\
\hline $\mathrm{O} 1$ & $-0.00432(7)$ & $0.4511(2)$ & $0.08868(6)$ & $0.0283(3)$ \\
\hline $\mathrm{O} 4$ & $0.30880(7)$ & $0.4406(2)$ & $0.20139(5)$ & $0.0240(3)$ \\
\hline $\mathrm{C} 1$ & $0.06668(9)$ & $0.4618(3)$ & $0.11528(7)$ & $0.0212(3)$ \\
\hline $\mathrm{C} 2$ & $0.10318(9)$ & $0.2887(3)$ & $0.17016(7)$ & $0.0212(3)$ \\
\hline $\mathrm{C} 3$ & $0.18140(9)$ & $0.2861(3)$ & $0.19828(7)$ & $0.0220(3)$ \\
\hline $\mathrm{H} 3$ & 0.2015 & 0.1702 & 0.2328 & $0.026^{*}$ \\
\hline $\mathrm{C} 4$ & $0.23713(9)$ & $0.4592(3)$ & $0.17689(7)$ & $0.0193(3)$ \\
\hline $\mathrm{C} 4 \mathrm{~A}$ & $0.20374(8)$ & $0.6514(3)$ & $0.12522(6)$ & 0.0189 (3) \\
\hline $\mathrm{C} 5$ & $0.25340(9)$ & $0.8282(3)$ & $0.10564(7)$ & 0.0221 \\
\hline H5 & 0.3089 & 0.8299 & 0.1259 & $0.027^{*}$ \\
\hline C6 & $0.22192(10)$ & $1.0033(4)$ & $0.05623(7)$ & 0.0255 (3) \\
\hline H6 & 0.2558 & 1.1259 & 0.0431 & $0.031^{*}$ \\
\hline $\mathrm{C} 7$ & 0.14060 (11) & 0.9984 (4) & $0.02611(8)$ & $0.0271(3)$ \\
\hline H7 & 0.1192 & 1.1172 & -0.0077 & $0.032 *$ \\
\hline $\mathrm{C} 8$ & $0.09098(9)$ & 0.8207 (3) & $0.04535(7)$ & 0.0248 (3) \\
\hline H8 & 0.0357 & 0.8171 & 0.0244 & $0.030^{*}$ \\
\hline C8A & $0.12158(9)$ & $0.6468(3)$ & $0.09523(7)$ & 0.0198 (3) \\
\hline O11 & $0.36741(7)$ & $-0.0561(2)$ & $0.48553(5)$ & $0.0244(3)$ \\
\hline H11O & $0.4113(8)$ & $0.004(5)$ & $0.4841(10)$ & $0.037^{*}$ \\
\hline $\mathrm{O} 18$ & $0.58338(6)$ & $0.5207(3)$ & $0.42739(5)$ & $0.0245(2)$ \\
\hline H18O & $0.5660(13)$ & $0.396(4)$ & $0.4450(9)$ & $0.037 *$ \\
\hline O19 & $0.47299(6)$ & $0.2395(2)$ & $0.45660(5)$ & $0.0217(2)$ \\
\hline $\mathrm{O} 20$ & $0.24399(6)$ & $0.7932(2)$ & $0.29021(5)$ & $0.0261(2)$ \\
\hline C11 & $0.31370(9)$ & $0.0927(3)$ & $0.44373(7)$ & 0.0199 (3) \\
\hline $\mathrm{C} 12$ & $0.23328(10)$ & $0.0292(3)$ & $0.43377(7)$ & $0.0229(3)$ \\
\hline H12 & 0.2184 & -0.1123 & 0.4570 & $0.027^{*}$ \\
\hline $\mathrm{C} 13$ & $0.17525(9)$ & $0.1711(4)$ & $0.39025(7)$ & $0.0251(3)$ \\
\hline H13 & 0.1208 & 0.1253 & 0.3837 & $0.030^{*}$ \\
\hline C14 & $0.19585(9)$ & $0.3800(4)$ & $0.35607(7)$ & $0.0234(3)$ \\
\hline H14 & 0.1556 & 0.4771 & 0.3265 & $0.028^{*}$ \\
\hline $\mathrm{C} 15$ & $0.40221(10)$ & 0.9337 (3) & $0.30130(7)$ & $0.0230(3)$ \\
\hline H15 & 0.3619 & 1.0299 & 0.2716 & $0.028^{*}$ \\
\hline C16 & $0.48208(11)$ & 0.9953 (4) & $0.30923(7)$ & $0.0251(3)$ \\
\hline H16 & 0.4960 & 1.1350 & 0.2851 & $0.030^{*}$ \\
\hline $\mathrm{C} 17$ & $0.54127(9)$ & 0.8551 (3) & $0.35188(7)$ & $0.0236(3)$ \\
\hline H17 & 0.5955 & 0.8990 & 0.3568 & $0.028^{*}$ \\
\hline
\end{tabular}




$\begin{array}{lllll}\text { C18 } & 0.52207(9) & 0.6495(3) & 0.38783(7) & 0.0206(3) \\ \text { C19 } & 0.41987(9) & 0.3695(3) & 0.41798(6) & 0.0183(3) \\ \text { C20 } & 0.29639(9) & 0.6680(3) & 0.32790(6) & 0.0200(3) \\ \text { C21 } & 0.38191(9) & 0.7318(3) & 0.33688(7) & 0.0197(3) \\ \text { C22 } & 0.44137(9) & 0.5846(3) & 0.38098(7) & 0.0179(3) \\ \text { C23 } & 0.33587(8) & 0.3038(3) & 0.40931(6) & 0.0180(3) \\ \text { C24 } & 0.27558(9) & 0.4463(3) & 0.36537(7) & 0.0193(3)\end{array}$

Atomic displacement parameters $\left(\AA^{2}\right)$

\begin{tabular}{|c|c|c|c|c|c|c|}
\hline & $U^{11}$ & $U^{22}$ & $U^{33}$ & $U^{12}$ & $U^{13}$ & $U^{23}$ \\
\hline $\mathrm{Br} 1$ & 0.02564 (12) & 0.02819 (13) & 0.03685 (13) & $-0.00434(6)$ & $0.01723(9)$ & $-0.00040(6)$ \\
\hline $\mathrm{O} 1$ & $0.0168(5)$ & $0.0350(7)$ & $0.0321(6)$ & 0.0009 (4) & $0.0054(5)$ & $-0.0024(5)$ \\
\hline $\mathrm{O} 4$ & $0.0182(5)$ & $0.0298(7)$ & $0.0237(5)$ & $0.0035(4)$ & 0.0055 (4) & $0.0024(4)$ \\
\hline $\mathrm{C} 1$ & $0.0180(7)$ & $0.0225(8)$ & $0.0239(7)$ & $0.0026(6)$ & $0.0072(6)$ & $-0.0046(6)$ \\
\hline $\mathrm{C} 2$ & $0.0216(7)$ & $0.0202(7)$ & $0.0250(7)$ & $-0.0003(6)$ & $0.0118(6)$ & $-0.0018(6)$ \\
\hline $\mathrm{C} 3$ & 0.0239 (7) & $0.0212(7)$ & $0.0220(7)$ & $0.0032(6)$ & $0.0085(6)$ & $0.0019(6)$ \\
\hline $\mathrm{C} 4$ & $0.0194(7)$ & $0.0199(8)$ & $0.0194(7)$ & $0.0020(6)$ & $0.0070(6)$ & $-0.0017(5)$ \\
\hline C4A & $0.0179(7)$ & $0.0195(7)$ & $0.0201(7)$ & 0.0035 (6) & $0.0066(5)$ & $-0.0010(6)$ \\
\hline C5 & $0.0211(7)$ & $0.0226(8)$ & $0.0242(7)$ & $0.0031(6)$ & $0.0091(6)$ & $-0.0004(6)$ \\
\hline $\mathrm{C} 6$ & $0.0303(9)$ & 0.0227 (7) & 0.0277 (8) & $0.0036(7)$ & $0.0151(7)$ & $0.0023(7)$ \\
\hline $\mathrm{C} 7$ & $0.0327(9)$ & $0.0261(8)$ & $0.0242(8)$ & $0.0094(7)$ & $0.0111(7)$ & $0.0046(7)$ \\
\hline $\mathrm{C} 8$ & $0.0233(7)$ & $0.0269(8)$ & $0.0229(7)$ & 0.0067 (6) & 0.0049 (6) & $0.0016(6)$ \\
\hline $\mathrm{C} 8 \mathrm{~A}$ & $0.0180(7)$ & 0.0205 (7) & $0.0212(7)$ & $0.0038(6)$ & $0.0064(5)$ & $-0.0019(6)$ \\
\hline O11 & $0.0228(6)$ & $0.0244(6)$ & $0.0265(6)$ & $-0.0019(4)$ & 0.0077 (5) & 0.0069 (4) \\
\hline $\mathrm{O} 18$ & $0.0180(5)$ & $0.0250(6)$ & $0.0315(6)$ & $-0.0010(5)$ & $0.0086(4)$ & $0.0047(5)$ \\
\hline O19 & $0.0182(5)$ & $0.0232(5)$ & $0.0233(5)$ & $0.0006(4)$ & 0.0052 (4) & 0.0045 (4) \\
\hline $\mathrm{O} 20$ & $0.0241(5)$ & $0.0279(6)$ & $0.0257(5)$ & $0.0058(5)$ & 0.0061 (4) & $0.0049(5)$ \\
\hline C11 & $0.0211(8)$ & $0.0196(7)$ & $0.0193(7)$ & $-0.0003(6)$ & 0.0064 (6) & $-0.0039(5)$ \\
\hline $\mathrm{C} 12$ & $0.0241(8)$ & $0.0239(8)$ & $0.0241(7)$ & $-0.0051(6)$ & $0.0125(6)$ & $-0.0023(6)$ \\
\hline $\mathrm{C} 13$ & $0.0186(7)$ & 0.0298 (9) & $0.0294(8)$ & $-0.0038(6)$ & 0.0109 (6) & $-0.0055(7)$ \\
\hline $\mathrm{C} 14$ & $0.0190(7)$ & $0.0272(8)$ & $0.0235(7)$ & $0.0019(6)$ & $0.0053(6)$ & $-0.0030(6)$ \\
\hline $\mathrm{C} 15$ & $0.0293(8)$ & $0.0195(8)$ & $0.0220(7)$ & $0.0024(6)$ & $0.0100(6)$ & $0.0006(5)$ \\
\hline C16 & $0.0352(8)$ & $0.0202(7)$ & $0.0253(8)$ & $-0.0024(7)$ & $0.0172(7)$ & 0.0009 (7) \\
\hline $\mathrm{C} 17$ & $0.0233(7)$ & $0.0238(8)$ & $0.0280(8)$ & $-0.0037(6)$ & $0.0144(6)$ & $-0.0035(7)$ \\
\hline $\mathrm{C} 18$ & $0.0210(7)$ & $0.0195(7)$ & $0.0228(7)$ & $-0.0002(6)$ & $0.0088(6)$ & $-0.0039(6)$ \\
\hline C19 & $0.0196(7)$ & $0.0176(7)$ & $0.0185(7)$ & $0.0002(6)$ & $0.0066(5)$ & $-0.0032(6)$ \\
\hline $\mathrm{C} 20$ & $0.0226(7)$ & $0.0196(7)$ & $0.0184(7)$ & $0.0021(6)$ & $0.0068(6)$ & $-0.0016(6)$ \\
\hline $\mathrm{C} 21$ & $0.0225(7)$ & $0.0184(7)$ & $0.0197(7)$ & $0.0006(6)$ & $0.0085(5)$ & $-0.0019(6)$ \\
\hline $\mathrm{C} 22$ & $0.0194(7)$ & $0.0172(7)$ & $0.0190(7)$ & $-0.0005(5)$ & $0.0083(6)$ & $-0.0022(5)$ \\
\hline $\mathrm{C} 23$ & $0.0185(7)$ & $0.0179(7)$ & 0.0187 (6) & $-0.0006(6)$ & $0.0072(5)$ & $-0.0020(5)$ \\
\hline C24 & $0.0196(7)$ & $0.0201(8)$ & $0.0195(7)$ & $0.0004(5)$ & $0.0074(6)$ & $-0.0026(5)$ \\
\hline
\end{tabular}

Geometric parameters $\left(A,{ }^{\circ}\right)$

\begin{tabular}{llll}
\hline $\mathrm{Br} 1-\mathrm{C} 2$ & $1.8857(15)$ & $\mathrm{O} 20-\mathrm{C} 20$ & $1.2248(18)$ \\
$\mathrm{O} 1-\mathrm{C} 1$ & $1.220(2)$ & $\mathrm{C} 11-\mathrm{C} 12$ & $1.398(2)$ \\
$\mathrm{O} 4-\mathrm{C} 4$ & $1.2239(19)$ & $\mathrm{C} 11-\mathrm{C} 23$ & $1.413(2)$
\end{tabular}




\begin{tabular}{|c|c|c|c|}
\hline $\mathrm{C} 1-\mathrm{C} 8 \mathrm{~A}$ & $1.483(2)$ & $\mathrm{C} 12-\mathrm{C} 13$ & $1.385(2)$ \\
\hline $\mathrm{C} 1-\mathrm{C} 2$ & $1.492(2)$ & $\mathrm{C} 12-\mathrm{H} 12$ & 0.9500 \\
\hline $\mathrm{C} 2-\mathrm{C} 3$ & $1.338(2)$ & $\mathrm{C} 13-\mathrm{C} 14$ & $1.390(2)$ \\
\hline $\mathrm{C} 3-\mathrm{C} 4$ & $1.476(2)$ & $\mathrm{C} 13-\mathrm{H} 13$ & 0.9500 \\
\hline $\mathrm{C} 3-\mathrm{H} 3$ & 0.9500 & $\mathrm{C} 14-\mathrm{C} 24$ & $1.391(2)$ \\
\hline $\mathrm{C} 4-\mathrm{C} 4 \mathrm{~A}$ & $1.486(2)$ & $\mathrm{C} 14-\mathrm{H} 14$ & 0.9500 \\
\hline $\mathrm{C} 4 \mathrm{~A}-\mathrm{C} 5$ & $1.386(2)$ & $\mathrm{C} 15-\mathrm{C} 21$ & $1.384(2)$ \\
\hline $\mathrm{C} 4 \mathrm{~A}-\mathrm{C} 8 \mathrm{~A}$ & $1.407(2)$ & $\mathrm{C} 15-\mathrm{C} 16$ & $1.393(2)$ \\
\hline $\mathrm{C} 5-\mathrm{C} 6$ & $1.394(2)$ & $\mathrm{C} 15-\mathrm{H} 15$ & 0.9500 \\
\hline $\mathrm{C} 5-\mathrm{H} 5$ & 0.9500 & $\mathrm{C} 16-\mathrm{C} 17$ & $1.382(2)$ \\
\hline $\mathrm{C} 6-\mathrm{C} 7$ & $1.395(2)$ & $\mathrm{C} 16-\mathrm{H} 16$ & 0.9500 \\
\hline $\mathrm{C} 6-\mathrm{H} 6$ & 0.9500 & $\mathrm{C} 17-\mathrm{C} 18$ & $1.395(2)$ \\
\hline $\mathrm{C} 7-\mathrm{C} 8$ & $1.385(3)$ & $\mathrm{C} 17-\mathrm{H} 17$ & 0.9500 \\
\hline $\mathrm{C} 7-\mathrm{H} 7$ & 0.9500 & $\mathrm{C} 18-\mathrm{C} 22$ & $1.415(2)$ \\
\hline $\mathrm{C} 8-\mathrm{C} 8 \mathrm{~A}$ & $1.395(2)$ & $\mathrm{C} 19-\mathrm{C} 22$ & $1.460(2)$ \\
\hline $\mathrm{C} 8-\mathrm{H} 8$ & 0.9500 & $\mathrm{C} 19-\mathrm{C} 23$ & $1.465(2)$ \\
\hline $\mathrm{O} 11-\mathrm{C} 11$ & $1.3433(19)$ & $\mathrm{C} 20-\mathrm{C} 24$ & $1.485(2)$ \\
\hline $\mathrm{O} 11-\mathrm{H} 11 \mathrm{O}$ & $0.833(10)$ & $\mathrm{C} 20-\mathrm{C} 21$ & $1.488(2)$ \\
\hline $\mathrm{O} 18-\mathrm{C} 18$ & $1.3436(19)$ & $\mathrm{C} 21-\mathrm{C} 22$ & $1.417(2)$ \\
\hline $\mathrm{O} 18-\mathrm{H} 18 \mathrm{O}$ & $0.831(10)$ & $\mathrm{C} 23-\mathrm{C} 24$ & $1.412(2)$ \\
\hline $\mathrm{O} 19-\mathrm{C} 19$ & $1.2541(18)$ & & \\
\hline $\mathrm{O} 1-\mathrm{C} 1-\mathrm{C} 8 \mathrm{~A}$ & $122.25(15)$ & $\mathrm{C} 11-\mathrm{C} 12-\mathrm{H} 12$ & 119.8 \\
\hline $\mathrm{O} 1-\mathrm{C} 1-\mathrm{C} 2$ & $121.59(15)$ & $\mathrm{C} 12-\mathrm{C} 13-\mathrm{C} 14$ & $120.66(14)$ \\
\hline $\mathrm{C} 8 \mathrm{~A}-\mathrm{C} 1-\mathrm{C} 2$ & $116.16(13)$ & $\mathrm{C} 12-\mathrm{C} 13-\mathrm{H} 13$ & 119.7 \\
\hline $\mathrm{C} 3-\mathrm{C} 2-\mathrm{C} 1$ & $122.79(14)$ & $\mathrm{C} 14-\mathrm{C} 13-\mathrm{H} 13$ & 119.7 \\
\hline $\mathrm{C} 3-\mathrm{C} 2-\mathrm{Br} 1$ & $120.42(12)$ & $\mathrm{C} 24-\mathrm{C} 14-\mathrm{C} 13$ & $119.74(14)$ \\
\hline $\mathrm{C} 1-\mathrm{C} 2-\mathrm{Br} 1$ & $116.79(11)$ & $\mathrm{C} 24-\mathrm{C} 14-\mathrm{H} 14$ & 120.1 \\
\hline $\mathrm{C} 2-\mathrm{C} 3-\mathrm{C} 4$ & $121.47(14)$ & $\mathrm{C} 13-\mathrm{C} 14-\mathrm{H} 14$ & 120.1 \\
\hline $\mathrm{C} 2-\mathrm{C} 3-\mathrm{H} 3$ & 119.3 & $\mathrm{C} 21-\mathrm{C} 15-\mathrm{C} 16$ & $119.69(15)$ \\
\hline $\mathrm{C} 4-\mathrm{C} 3-\mathrm{H} 3$ & 119.3 & $\mathrm{C} 21-\mathrm{C} 15-\mathrm{H} 15$ & 120.2 \\
\hline $\mathrm{O} 4-\mathrm{C} 4-\mathrm{C} 3$ & $119.89(14)$ & $\mathrm{C} 16-\mathrm{C} 15-\mathrm{H} 15$ & 120.2 \\
\hline $\mathrm{O} 4-\mathrm{C} 4-\mathrm{C} 4 \mathrm{~A}$ & $121.84(14)$ & $\mathrm{C} 17-\mathrm{C} 16-\mathrm{C} 15$ & $120.65(15)$ \\
\hline $\mathrm{C} 3-\mathrm{C} 4-\mathrm{C} 4 \mathrm{~A}$ & $118.26(13)$ & $\mathrm{C} 17-\mathrm{C} 16-\mathrm{H} 16$ & 119.7 \\
\hline $\mathrm{C} 5-\mathrm{C} 4 \mathrm{~A}-\mathrm{C} 8 \mathrm{~A}$ & $120.29(14)$ & $\mathrm{C} 15-\mathrm{C} 16-\mathrm{H} 16$ & 119.7 \\
\hline $\mathrm{C} 5-\mathrm{C} 4 \mathrm{~A}-\mathrm{C} 4$ & $120.30(13)$ & $\mathrm{C} 16-\mathrm{C} 17-\mathrm{C} 18$ & $120.53(15)$ \\
\hline $\mathrm{C} 8 \mathrm{~A}-\mathrm{C} 4 \mathrm{~A}-\mathrm{C} 4$ & $119.38(14)$ & $\mathrm{C} 16-\mathrm{C} 17-\mathrm{H} 17$ & 119.7 \\
\hline $\mathrm{C} 4 \mathrm{~A}-\mathrm{C} 5-\mathrm{C} 6$ & $119.99(14)$ & $\mathrm{C} 18-\mathrm{C} 17-\mathrm{H} 17$ & 119.7 \\
\hline $\mathrm{C} 4 \mathrm{~A}-\mathrm{C} 5-\mathrm{H} 5$ & 120.0 & $\mathrm{O} 18-\mathrm{C} 18-\mathrm{C} 17$ & $116.53(14)$ \\
\hline $\mathrm{C} 6-\mathrm{C} 5-\mathrm{H} 5$ & 120.0 & $\mathrm{O} 18-\mathrm{C} 18-\mathrm{C} 22$ & $123.57(14)$ \\
\hline $\mathrm{C} 7-\mathrm{C} 6-\mathrm{C} 5$ & $119.96(16)$ & $\mathrm{C} 17-\mathrm{C} 18-\mathrm{C} 22$ & $119.90(14)$ \\
\hline $\mathrm{C} 7-\mathrm{C} 6-\mathrm{H} 6$ & 120.0 & $\mathrm{O} 19-\mathrm{C} 19-\mathrm{C} 22$ & $120.26(13)$ \\
\hline $\mathrm{C} 5-\mathrm{C} 6-\mathrm{H} 6$ & 120.0 & $\mathrm{O} 19-\mathrm{C} 19-\mathrm{C} 23$ & $120.02(14)$ \\
\hline $\mathrm{C} 8-\mathrm{C} 7-\mathrm{C} 6$ & $120.14(15)$ & $\mathrm{C} 22-\mathrm{C} 19-\mathrm{C} 23$ & $119.71(13)$ \\
\hline $\mathrm{C} 8-\mathrm{C} 7-\mathrm{H} 7$ & 119.9 & $\mathrm{O} 20-\mathrm{C} 20-\mathrm{C} 24$ & $120.36(14)$ \\
\hline $\mathrm{C} 6-\mathrm{C} 7-\mathrm{H} 7$ & 119.9 & $\mathrm{O} 20-\mathrm{C} 20-\mathrm{C} 21$ & $121.12(14)$ \\
\hline $\mathrm{C} 7-\mathrm{C} 8-\mathrm{C} 8 \mathrm{~A}$ & $120.47(15)$ & $\mathrm{C} 24-\mathrm{C} 20-\mathrm{C} 21$ & $118.52(13)$ \\
\hline $\mathrm{C} 7-\mathrm{C} 8-\mathrm{H} 8$ & 119.8 & $\mathrm{C} 15-\mathrm{C} 21-\mathrm{C} 22$ & $120.88(14)$ \\
\hline
\end{tabular}




\begin{tabular}{|c|c|c|c|}
\hline $\mathrm{C} 8 \mathrm{~A}-\mathrm{C} 8-\mathrm{H} 8$ & 119.8 & $\mathrm{C} 15-\mathrm{C} 21-\mathrm{C} 20$ & $119.13(14)$ \\
\hline $\mathrm{C} 8-\mathrm{C} 8 \mathrm{~A}-\mathrm{C} 4 \mathrm{~A}$ & $119.15(15)$ & $\mathrm{C} 22-\mathrm{C} 21-\mathrm{C} 20$ & $119.99(14)$ \\
\hline $\mathrm{C} 8-\mathrm{C} 8 \mathrm{~A}-\mathrm{C} 1$ & $119.16(14)$ & $\mathrm{C} 18-\mathrm{C} 22-\mathrm{C} 21$ & $118.35(14)$ \\
\hline $\mathrm{C} 4 \mathrm{~A}-\mathrm{C} 8 \mathrm{~A}-\mathrm{C} 1$ & $121.69(14)$ & $\mathrm{C} 18-\mathrm{C} 22-\mathrm{C} 19$ & $120.85(14)$ \\
\hline $\mathrm{C} 11-\mathrm{O} 11-\mathrm{H} 11 \mathrm{O}$ & $104.5(16)$ & $\mathrm{C} 21-\mathrm{C} 22-\mathrm{C} 19$ & $120.80(14)$ \\
\hline $\mathrm{C} 18-\mathrm{O} 18-\mathrm{H} 18 \mathrm{O}$ & $109.2(16)$ & $\mathrm{C} 24-\mathrm{C} 23-\mathrm{C} 11$ & $118.74(13)$ \\
\hline $\mathrm{O} 11-\mathrm{C} 11-\mathrm{C} 12$ & $117.75(14)$ & $\mathrm{C} 24-\mathrm{C} 23-\mathrm{C} 19$ & $120.53(13)$ \\
\hline $\mathrm{O} 11-\mathrm{C} 11-\mathrm{C} 23$ & $122.46(14)$ & $\mathrm{C} 11-\mathrm{C} 23-\mathrm{C} 19$ & $120.71(13)$ \\
\hline $\mathrm{C} 12-\mathrm{C} 11-\mathrm{C} 23$ & $119.78(14)$ & $\mathrm{C} 14-\mathrm{C} 24-\mathrm{C} 23$ & $120.66(14)$ \\
\hline $\mathrm{C} 13-\mathrm{C} 12-\mathrm{C} 11$ & $120.41(15)$ & $\mathrm{C} 14-\mathrm{C} 24-\mathrm{C} 20$ & $118.90(14)$ \\
\hline $\mathrm{C} 13-\mathrm{C} 12-\mathrm{H} 12$ & 119.8 & $\mathrm{C} 23-\mathrm{C} 24-\mathrm{C} 20$ & $120.44(13)$ \\
\hline $\mathrm{O} 1-\mathrm{C} 1-\mathrm{C} 2-\mathrm{C} 3$ & $176.47(15)$ & $\mathrm{C} 16-\mathrm{C} 15-\mathrm{C} 21-\mathrm{C} 20$ & $-179.96(14)$ \\
\hline $\mathrm{C} 8 \mathrm{~A}-\mathrm{C} 1-\mathrm{C} 2-\mathrm{C} 3$ & $-3.6(2)$ & $\mathrm{O} 20-\mathrm{C} 20-\mathrm{C} 21-\mathrm{C} 15$ & $-0.9(2)$ \\
\hline $\mathrm{O} 1-\mathrm{C} 1-\mathrm{C} 2-\mathrm{Br} 1$ & $-3.0(2)$ & $\mathrm{C} 24-\mathrm{C} 20-\mathrm{C} 21-\mathrm{C} 15$ & $178.56(13)$ \\
\hline $\mathrm{C} 8 \mathrm{~A}-\mathrm{C} 1-\mathrm{C} 2-\mathrm{Br} 1$ & $176.89(11)$ & $\mathrm{O} 20-\mathrm{C} 20-\mathrm{C} 21-\mathrm{C} 22$ & $179.75(14)$ \\
\hline $\mathrm{C} 1-\mathrm{C} 2-\mathrm{C} 3-\mathrm{C} 4$ & $0.7(2)$ & $\mathrm{C} 24-\mathrm{C} 20-\mathrm{C} 21-\mathrm{C} 22$ & $-0.8(2)$ \\
\hline $\mathrm{Br} 1-\mathrm{C} 2-\mathrm{C} 3-\mathrm{C} 4$ & $-179.76(11)$ & $\mathrm{O} 18-\mathrm{C} 18-\mathrm{C} 22-\mathrm{C} 21$ & $-178.89(14)$ \\
\hline $\mathrm{C} 2-\mathrm{C} 3-\mathrm{C} 4-\mathrm{O} 4$ & $-175.82(15)$ & $\mathrm{C} 17-\mathrm{C} 18-\mathrm{C} 22-\mathrm{C} 21$ & $0.4(2)$ \\
\hline $\mathrm{C} 2-\mathrm{C} 3-\mathrm{C} 4-\mathrm{C} 4 \mathrm{~A}$ & $3.7(2)$ & $\mathrm{O} 18-\mathrm{C} 18-\mathrm{C} 22-\mathrm{C} 19$ & $0.5(2)$ \\
\hline $\mathrm{O} 4-\mathrm{C} 4-\mathrm{C} 4 \mathrm{~A}-\mathrm{C} 5$ & $-3.8(2)$ & $\mathrm{C} 17-\mathrm{C} 18-\mathrm{C} 22-\mathrm{C} 19$ & $179.80(14)$ \\
\hline $\mathrm{C} 3-\mathrm{C} 4-\mathrm{C} 4 \mathrm{~A}-\mathrm{C} 5$ & $176.67(14)$ & $\mathrm{C} 15-\mathrm{C} 21-\mathrm{C} 22-\mathrm{C} 18$ & $0.1(2)$ \\
\hline $\mathrm{O} 4-\mathrm{C} 4-\mathrm{C} 4 \mathrm{~A}-\mathrm{C} 8 \mathrm{~A}$ & $174.35(14)$ & $\mathrm{C} 20-\mathrm{C} 21-\mathrm{C} 22-\mathrm{C} 18$ & $179.47(13)$ \\
\hline $\mathrm{C} 3-\mathrm{C} 4-\mathrm{C} 4 \mathrm{~A}-\mathrm{C} 8 \mathrm{~A}$ & $-5.2(2)$ & $\mathrm{C} 15-\mathrm{C} 21-\mathrm{C} 22-\mathrm{C} 19$ & $-179.30(14)$ \\
\hline $\mathrm{C} 8 \mathrm{~A}-\mathrm{C} 4 \mathrm{~A}-\mathrm{C} 5-\mathrm{C} 6$ & $0.3(2)$ & $\mathrm{C} 20-\mathrm{C} 21-\mathrm{C} 22-\mathrm{C} 19$ & $0.1(2)$ \\
\hline $\mathrm{C} 4-\mathrm{C} 4 \mathrm{~A}-\mathrm{C} 5-\mathrm{C} 6$ & $178.50(14)$ & $\mathrm{O} 19-\mathrm{C} 19-\mathrm{C} 22-\mathrm{C} 18$ & $0.2(2)$ \\
\hline $\mathrm{C} 4 \mathrm{~A}-\mathrm{C} 5-\mathrm{C} 6-\mathrm{C} 7$ & $-0.7(2)$ & $\mathrm{C} 23-\mathrm{C} 19-\mathrm{C} 22-\mathrm{C} 18$ & $-179.10(13)$ \\
\hline $\mathrm{C} 5-\mathrm{C} 6-\mathrm{C} 7-\mathrm{C} 8$ & $0.3(3)$ & $\mathrm{O} 19-\mathrm{C} 19-\mathrm{C} 22-\mathrm{C} 21$ & $179.56(13)$ \\
\hline $\mathrm{C} 6-\mathrm{C} 7-\mathrm{C} 8-\mathrm{C} 8 \mathrm{~A}$ & $0.5(3)$ & $\mathrm{C} 23-\mathrm{C} 19-\mathrm{C} 22-\mathrm{C} 21$ & $0.3(2)$ \\
\hline $\mathrm{C} 7-\mathrm{C} 8-\mathrm{C} 8 \mathrm{~A}-\mathrm{C} 4 \mathrm{~A}$ & $-0.9(2)$ & $\mathrm{O} 11-\mathrm{C} 11-\mathrm{C} 23-\mathrm{C} 24$ & $178.68(13)$ \\
\hline $\mathrm{C} 7-\mathrm{C} 8-\mathrm{C} 8 \mathrm{~A}-\mathrm{C} 1$ & $179.08(15)$ & $\mathrm{C} 12-\mathrm{C} 11-\mathrm{C} 23-\mathrm{C} 24$ & $0.0(2)$ \\
\hline $\mathrm{C} 5-\mathrm{C} 4 \mathrm{~A}-\mathrm{C} 8 \mathrm{~A}-\mathrm{C} 8$ & $0.5(2)$ & $\mathrm{O} 11-\mathrm{C} 11-\mathrm{C} 23-\mathrm{C} 19$ & $0.1(2)$ \\
\hline $\mathrm{C} 4-\mathrm{C} 4 \mathrm{~A}-\mathrm{C} 8 \mathrm{~A}-\mathrm{C} 8$ & $-177.71(14)$ & $\mathrm{C} 12-\mathrm{C} 11-\mathrm{C} 23-\mathrm{C} 19$ & $-178.57(14)$ \\
\hline $\mathrm{C} 5-\mathrm{C} 4 \mathrm{~A}-\mathrm{C} 8 \mathrm{~A}-\mathrm{C} 1$ & $-179.51(14)$ & $\mathrm{O} 19-\mathrm{C} 19-\mathrm{C} 23-\mathrm{C} 24$ & $-179.12(13)$ \\
\hline $\mathrm{C} 4-\mathrm{C} 4 \mathrm{~A}-\mathrm{C} 8 \mathrm{~A}-\mathrm{C} 1$ & $2.3(2)$ & $\mathrm{C} 22-\mathrm{C} 19-\mathrm{C} 23-\mathrm{C} 24$ & $0.2(2)$ \\
\hline $\mathrm{O} 1-\mathrm{C} 1-\mathrm{C} 8 \mathrm{~A}-\mathrm{C} 8$ & $1.9(2)$ & $\mathrm{O} 19-\mathrm{C} 19-\mathrm{C} 23-\mathrm{C} 11$ & $-0.6(2)$ \\
\hline $\mathrm{C} 2-\mathrm{C} 1-\mathrm{C} 8 \mathrm{~A}-\mathrm{C} 8$ & $-178.02(14)$ & $\mathrm{C} 22-\mathrm{C} 19-\mathrm{C} 23-\mathrm{C} 11$ & $178.72(13)$ \\
\hline $\mathrm{O} 1-\mathrm{C} 1-\mathrm{C} 8 \mathrm{~A}-\mathrm{C} 4 \mathrm{~A}$ & $-178.11(15)$ & $\mathrm{C} 13-\mathrm{C} 14-\mathrm{C} 24-\mathrm{C} 23$ & $-0.1(2)$ \\
\hline $\mathrm{C} 2-\mathrm{C} 1-\mathrm{C} 8 \mathrm{~A}-\mathrm{C} 4 \mathrm{~A}$ & $2.0(2)$ & $\mathrm{C} 13-\mathrm{C} 14-\mathrm{C} 24-\mathrm{C} 20$ & $179.34(14)$ \\
\hline $\mathrm{O} 11-\mathrm{C} 11-\mathrm{C} 12-\mathrm{C} 13$ & $-178.50(14)$ & $\mathrm{C} 11-\mathrm{C} 23-\mathrm{C} 24-\mathrm{C} 14$ & $-0.1(2)$ \\
\hline $\mathrm{C} 23-\mathrm{C} 11-\mathrm{C} 12-\mathrm{C} 13$ & $0.2(2)$ & $\mathrm{C} 19-\mathrm{C} 23-\mathrm{C} 24-\mathrm{C} 14$ & $178.52(14)$ \\
\hline $\mathrm{C} 11-\mathrm{C} 12-\mathrm{C} 13-\mathrm{C} 14$ & $-0.4(2)$ & $\mathrm{C} 11-\mathrm{C} 23-\mathrm{C} 24-\mathrm{C} 20$ & $-179.52(13)$ \\
\hline $\mathrm{C} 12-\mathrm{C} 13-\mathrm{C} 14-\mathrm{C} 24$ & $0.4(2)$ & $\mathrm{C} 19-\mathrm{C} 23-\mathrm{C} 24-\mathrm{C} 20$ & $-0.9(2)$ \\
\hline $\mathrm{C} 21-\mathrm{C} 15-\mathrm{C} 16-\mathrm{C} 17$ & $0.6(2)$ & $\mathrm{O} 20-\mathrm{C} 20-\mathrm{C} 24-\mathrm{C} 14$ & $1.2(2)$ \\
\hline $\mathrm{C} 15-\mathrm{C} 16-\mathrm{C} 17-\mathrm{C} 18$ & $-0.1(2)$ & $\mathrm{C} 21-\mathrm{C} 20-\mathrm{C} 24-\mathrm{C} 14$ & $-178.20(13)$ \\
\hline $\mathrm{C} 16-\mathrm{C} 17-\mathrm{C} 18-\mathrm{O} 18$ & $178.93(14)$ & $\mathrm{O} 20-\mathrm{C} 20-\mathrm{C} 24-\mathrm{C} 23$ & $-179.31(14)$ \\
\hline $\mathrm{C} 16-\mathrm{C} 17-\mathrm{C} 18-\mathrm{C} 22$ & $-0.4(2)$ & $\mathrm{C} 21-\mathrm{C} 20-\mathrm{C} 24-\mathrm{C} 23$ & $1.3(2)$ \\
\hline $\mathrm{C} 16-\mathrm{C} 15-\mathrm{C} 21-\mathrm{C} 22$ & $-0.6(2)$ & & \\
\hline
\end{tabular}


supporting information

Hydrogen-bond geometry $\left(\AA,{ }^{\circ}\right)$

\begin{tabular}{lllll}
\hline$D-\mathrm{H} \cdots A$ & $D-\mathrm{H}$ & $\mathrm{H} \cdots A$ & $D \cdots A$ & $D-\mathrm{H} \cdots A$ \\
\hline $\mathrm{O} 11-\mathrm{H} 11 O \cdots \mathrm{O} 19$ & $0.83(2)$ & $1.81(2)$ & $2.5766(16)$ & $153(2)$ \\
$\mathrm{O} 18-\mathrm{H} 18 O \cdots \mathrm{O} 19$ & $0.83(2)$ & $1.89(2)$ & $2.6097(16)$ & $144(2)$ \\
$\mathrm{O} 11-\mathrm{H} 11 O \cdots \mathrm{O} 19^{\mathrm{i}}$ & $0.83(2)$ & $2.40(2)$ & $2.8730(16)$ & $117(2)$ \\
$\mathrm{O} 18-\mathrm{H} 18 O \cdots \mathrm{O} 11^{\mathrm{i}}$ & $0.83(2)$ & $2.35(2)$ & $2.9677(17)$ & $131(2)$ \\
$\mathrm{C} 3-\mathrm{H} 3 \cdots \mathrm{O} 20^{\mathrm{ii}}$ & 0.95 & 2.25 & $3.1657(18)$ & 161 \\
$\mathrm{C} 13-\mathrm{H} 13 \cdots \mathrm{O} 1^{\mathrm{iii}}$ & 0.95 & 2.46 & $3.348(2)$ & 156 \\
$\mathrm{C} 15-\mathrm{H} 15 \cdots \mathrm{O} 4^{\text {iv }}$ & 0.95 & 2.56 & $3.4358(18)$ & 153 \\
$\mathrm{C} 17-\mathrm{H} 17 \cdots 4^{v}$ & 0.95 & 2.43 & $3.228(2)$ & 141
\end{tabular}

Symmetry codes: (i) $-x+1,-y,-z+1$; (ii) $x, y-1, z$; (iii) $x,-y-1 / 2, z+1 / 2$; (iv) $x, y+1, z$; (v) $x+1,-y+1 / 2, z+1 / 2$. 